九州大学学術情報リポジトリ

Kyushu University Institutional Repository

The Mechanisms of Absorption And Excretion In A Solenogastre, Epimenia Verrucosa (Nierstrasz), Studied By Means of Injection Methods

Baba, Kikutaro

The Amakusa Marine Biological Laboratory, Tomioka, Kumamoto-ken.

https://doi.org/10.5109/22591

出版情報：九州大学大学院農学研究院紀要. 6 (4)，pp. 119-166，1940-04. Kyushu Imperial University バージョン：

権利関係: 
Journal of the Department of Agriculture, Kyūsyū Imperial University, Vol. 6, No. 4, April 1st, 1940

\title{
THE MECHANISMS OF ABSORPTION AND EX- CRETION IN A SOLENOGASTRE, EPIMENIA VERRUCOSA (NIERSTRASZ), STUDIED BY MEANS OF INJECTION METHODS ${ }^{1)}$
}

\author{
Kikutarô BABA
}

Plates 14-15

\section{CONTENTS}

$\begin{array}{lllllllllll}\text { A. General Anatomy } . . & \ldots & \ldots & \ldots & \ldots & \ldots & \ldots & \ldots & \ldots & \ldots & 121\end{array}$

$\begin{array}{llllllllll}\text { I. Digestive system } & \ldots & \ldots & \ldots & \ldots & \ldots & \ldots & \ldots & \ldots & 121\end{array}$

$\begin{array}{lllllllll}\text { II. Blood vascular system } & \ldots & \ldots & \ldots & \ldots & \ldots & \ldots & \ldots & 124\end{array}$

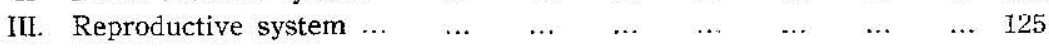

B. Topographic Histology $\ldots \begin{array}{llllllllll}\ldots & \ldots & \ldots & \ldots & \ldots & \ldots & \ldots & \ldots & \ldots & 127\end{array}$

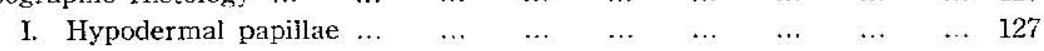

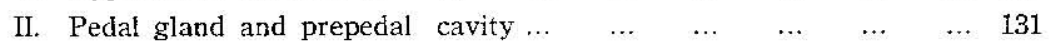

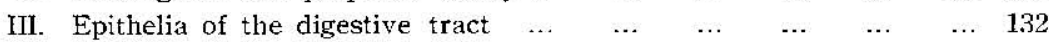

$\begin{array}{llllllllll}\text { IV. Salivary glands... } & \ldots & \ldots & \ldots & \ldots & \ldots & \ldots & \ldots & \ldots & 134\end{array}$

$\begin{array}{lllllllll}\text { V. Villous cells of the midgut } \ldots & \ldots & \ldots & \ldots & \ldots & \ldots & \ldots & 136\end{array}$

$\begin{array}{lllllllllllll}\text { VI. } & \text { Blood } & \ldots & \ldots & \ldots & \ldots & \ldots & \ldots & \ldots & \ldots & \ldots & \ldots & 144\end{array}$

VII. Epithelia of the pericardium and gono-pericardial canals $\quad \ldots \quad \ldots \quad 150$

$\begin{array}{lllllllllll}\text { VIII. Gonoducts } & \ldots & \ldots & \ldots & \ldots & \ldots & \ldots & \ldots & \ldots & \ldots & 151\end{array}$

$\begin{array}{llllllllllll}\text { C. Injection methods } \ldots & \ldots & \ldots & \ldots & \ldots & \ldots & \ldots & \ldots & \ldots & \ldots & 156\end{array}$

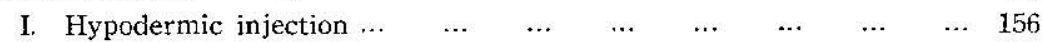

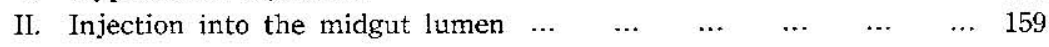

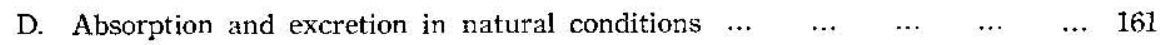

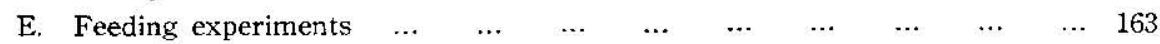

$\begin{array}{llllllllllllll}\text { F. Summary } & \ldots & \ldots & \ldots & \ldots & \ldots & \ldots & \ldots & \ldots & \ldots & \ldots & \ldots & 163\end{array}$

1) Contributions from the Zoological Laboratory, Kyūsyū Imperial Liniversity, No. 141. Papers from the Amakusa Marine Biological Laboratory, No. 74. 
In the solenogastres, the so-called nephridial organs issue from the postero-lateral corners of the pericardium, which, in turn, communicates in front with the gonad system through a pair of gonopericardial canals. Naturally the ova and sperms fall into the pericardial lumen whence they make their way to the outside through the nephridial organs in question. These latter are highly modified in adaptation for fertilisation and oviposition and therefore may preferably be termed gonoducts. Views widely diversified have hitherto been proposed regarding the actual mode of excretion in the organisation of the solenogastres. Many authors are inclined to consider that the gonoducts also function as excretory organs, because they are convinced of the physiological as well as anatomical homology between the solonogastre gonoducts and the nephridia of the chitons. Other investigators ascribe a presumable activity of elimination to different tissues: pre-anal gland, pedal gland, pericardial gland, hypodermal papillae, atrial cirri, etc.

The present work was begun primarily with the bope of determining as far as possible the nature and functions of the much disputed gonoducts and other tissues; using as material the solenogastre species, Epimenia vernucosa (NiERSTRAsz). Various methods of observation have been adopted: Morphological studies of organs in young and mature specimens. Organogenetic studies of developing embryos or of the tail part operated upon and regenerated. These methods of study have served to some extent to make clear the origin, development and minute structure of the aforesaid organs and tissues. But as to whether they actually exercise an excretory function, almost no satisfactory conclusion has been reached. Finally the injection methods were applied, by these the work has been expanded beyond my expectations, and owing to this fact I have, in the following pages, paid further particular attention to the absorption and excretion mechanisms of the amoebocytes as well as of the villous cells of the midgut wall.

The work was commenced in the spring of 1933 at the Amakusa Marine Biological Laboratory. It was greatly facilitated and strengthened by utilising the new seaside study rooms which were added in 1938 to this Laboratory, with aquarium tanks and various equipment for experimental use. In this connection it is the most pleasant duty to express my appreciation to the Director 
of the Laboratory, Dr. H. OHSHIMA, for giving me facilities for research and also for his criticisms made during the preparation of this manuscript. Not a few practical hints for study have been derived from the work of Dr. S. TAkatsuki on the Ostrea amoebocytes, to whom I here acknowledge my indebtedness.

\section{MATERIAL}

This solenogastre is not rare in the vicinity of the Laboratory. Wthout much difficulty it can be collected by a fishing net in fair numbers every year from spring to autumn (see BABA 1939). It is very hardy in nature, readily gets acclimatised in aquarium tanks, and survives there for two or three months without taking any food. Its size is enormous for a representative of the solenogastres. The sum of such favorable conditions as I have enumerated contributed both to the ease and to the success of the present work.

\section{A. GENERAL ANATOMY OF EPIMENIA VERRUCOSA}

(exclusive of Nervous System)

\section{Digestive System}

The digestive system consists of the following parts: atrium, foregut, midgut, rectum and cloaca. The atrium, foregut and cloaca are evidently derived from the ectoderm, while the midgut and rectum are of endodermal origin (see BABA 1938, pp. 30-31). The atrium (pl. 14, $\mathrm{n}$ ) is a narrow space facing directly to the exterior by an atrial opening. From the dorso-lateral walls of the atrium there hang down a pair of bundles of folds, known as cirri (pl. 14, a). A mouth-slit is formed between the atrium and the foregut, the size of this slit being controlled by means of an encircling ridge ( $\mathrm{pl} .14, \mathrm{~m}$ ). The wall of the foregut yields luxurious folds. Between it and the underside of the integument are rich bundles of muscular fibres running in different directions. A pair of salivary glands ( $\mathrm{pl} .14, \mathrm{~g}, \mathrm{j}$ ) debouch near the posterior end of the foregut, just in front of the radula (pl. 14, e; fig. 1, m). They arise as lateral diverticula of the foregut (see BABA 1938, pp. 30-31), but in the adult form they become exceedingly elon- 
gated, being differentiated into a glandular body and its duct. These two glands may run parallel or, more often, they cross each other (fig. 2), and are lying in the lacuna formed between

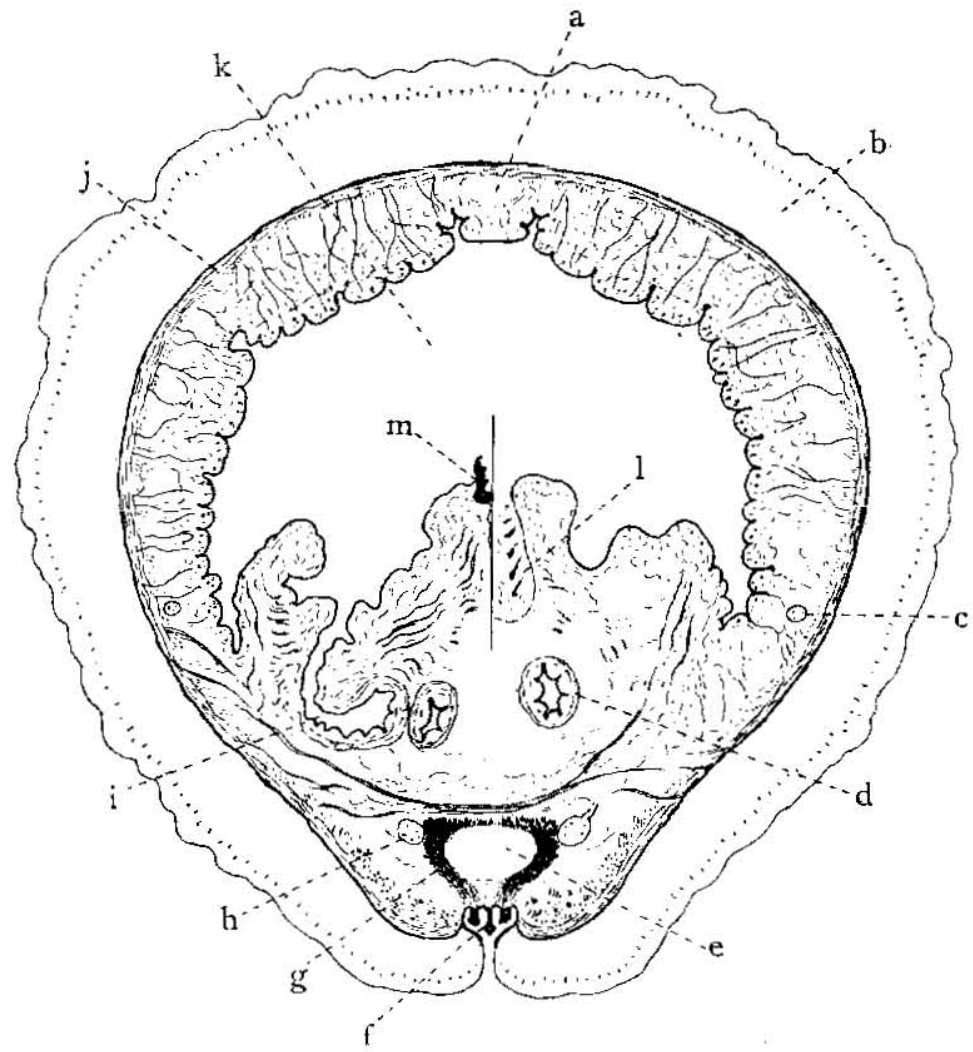

Fig 1.-Transverse section passing through the cephalic region, cut at the position shown by $\mathrm{A}-\mathrm{A}$ in plate $\mathrm{I}(\times 20)$. a. dorsal sinus, b. integumental cuticle, c. lateral nerve cord, d. duct of salivary gland, e. pedal sinus, f. pedal folds, g. pedal gland, h. pedal nerve cord, i. opening of salivary gland, j. subcutaneous muscle layers, k. pharynx, l. radula sac, m. radula tooth.

the floor of the midgut and the pedal furrow. The foregut passes into the midgut without any clear line of demarkation. The foremost region of the midgut develops a spacious lumen which is generally called pharynx (pl. 14, d; fig. 1, k). In life the wall of the pharynx is quite smooth, but it easily undergoes shrinkage 
after preservation. The remaining midgut (pls. $14, \mathrm{~h} ; 15, \mathrm{~m}$ ) occupies the greater part of the length of the body. Laterally and ventrally the wall is thrown into fine villous structures (fig. $3, \mathrm{~b}$ ),

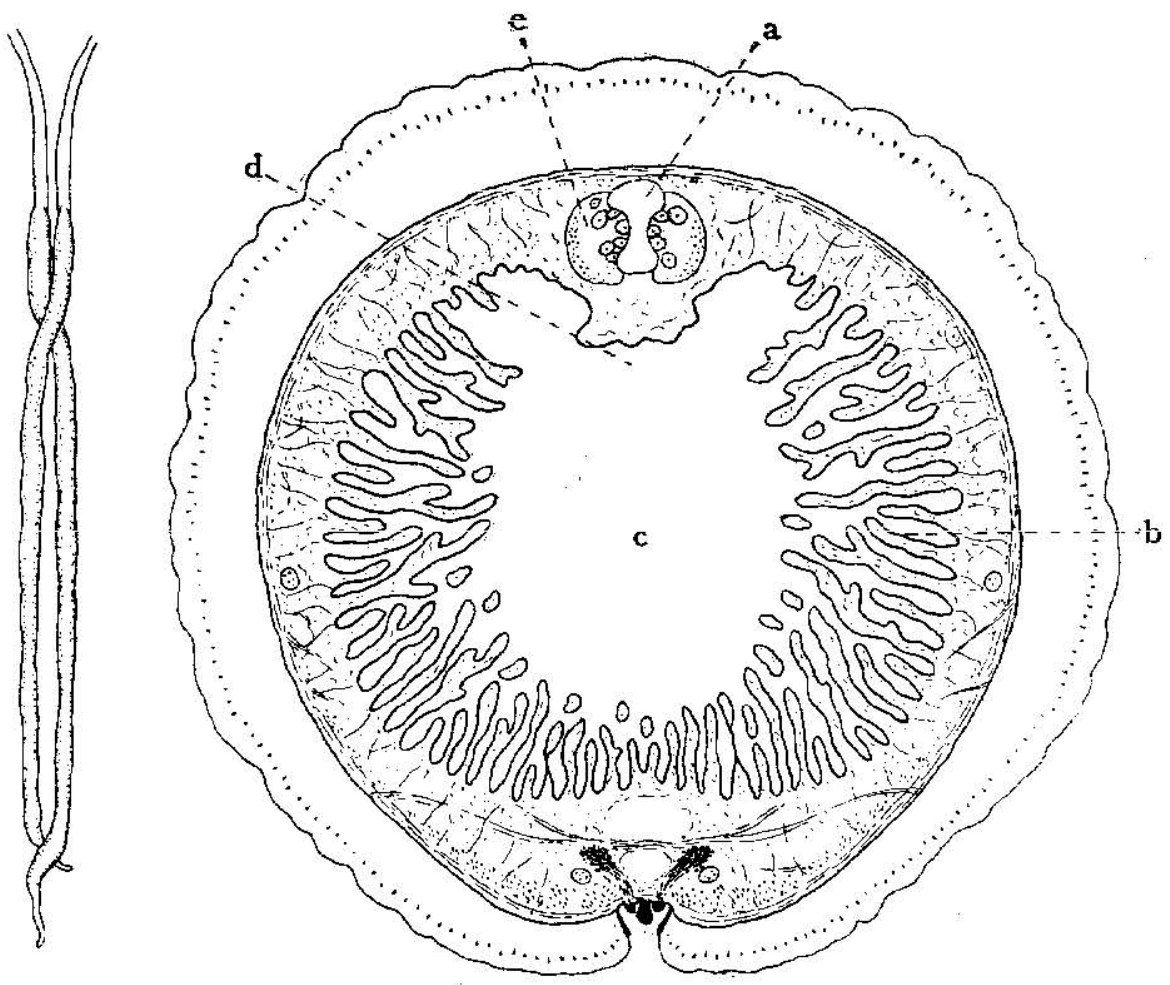

Fig. 2.-Salivary glands, showing the crossing of these organs.

Fig. 3.-Transverse section passing through the midgut region, cut at about the line $\mathrm{B}-\mathrm{B}$ in plate $14(\times 20)$. a. dorsal sinus, b. villi, c. midgut lumen, d. dorsal midgut tract, e. gonad.

while on the dorsal side it becomes thin and, in life, quite smooth, and is applied to the underside of the gonads. Towards the posterior end the midgut gradually narrows to pass into a short rectum which bears internal longitudinal folds (pl. 15, k; fig. 4, j). The cloaca is the direct posterior continuation of the rectum, and has likewise longitudinal folds (pl. 15, i ; fig. 5, i). On the dorso-lateral sides the cloaca is widened, more markedly on the dorsal proximal ends than elsewhere, and there forms an exceedingly capacious 'dorsal cloacal chamber', with a much thickened and convoluted 
epithelium (pl. 15, e). This chamber is incompletely divided into bilateral halves by a low downward folding of the median dorsal wall. The whole body of the cloaca as seen from above presents the general shape of a heart (fig. 5, g). It has a shallow depression along the median longitudinal line. A cloacal opening (pl. 15, h; fig. $5, \mathrm{~h}$ ) is situated ventrally near the posterior end of the body. No pre-anal gland is present in Epimenia verrucosa.

\section{Blood Vascular System}

The blood vascular system consists of a heart, arterial sinuses and venous sinuses. In addition, there are abundant lacunae in the connective tissue between the integument and visceral organs. The heart (pl. 15, c-d) lies on the back of the rectum, just in front

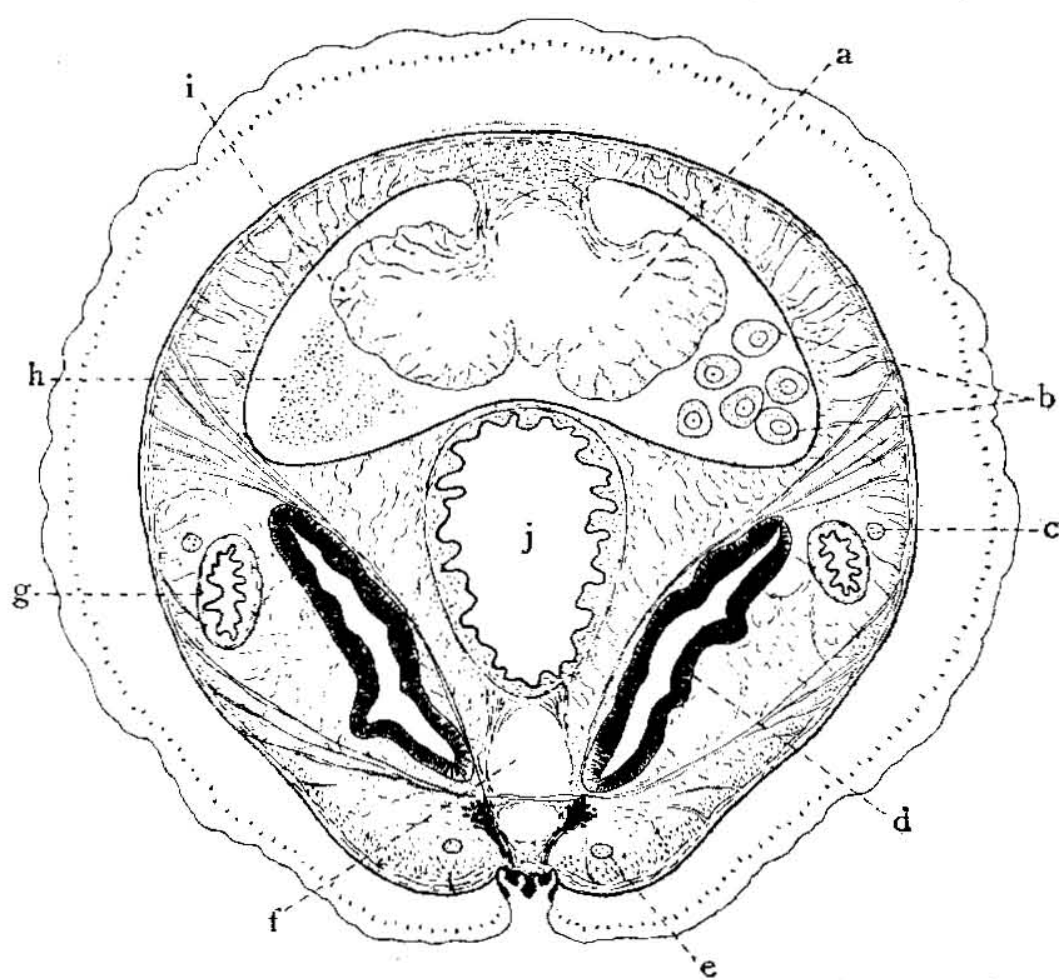

Fig. 4.-Transverse section cut through the caudal region, as shown by line $\mathrm{C}-\mathrm{C}$ in plate $15(\times 20)$. a. auricle, b. oocytes, c. lateral nerve cord, d. lower gonoduct, e. pedal nerve cord, f. pedal sinus, g. upper gonoduct, h. sperms, i. pericardial chamber, j. rectum. 
of the dorsal cloacal chamber. It is two-chambered. The auricle, situated posteriorly, appears superficially to be'bipartite, but actually it has a common lumen in the interior (figs. 4, a ; 5, f). A single caudai sinus (fig. $5, \mathrm{n}$ ) is in direct communication with the posterior aperture of the auricle. This sinus arises from near the posterior end of the cloaca, and passes forward along the middorsal depression of the same organ.

The ventricle (fig. 5, d) is larger than the auricle. There is a constriction between the ventricle and the auricle, marked internally by a sphincter which regulates the atrio-ventricular passage. In structure the ventricle is much like the auricle, though having a more compact and thicker wall. Fine interlacing strands of muscle and fibrous tissue give them the appearance of delicate lace.

From the anterior end of the ventricle arises a dorsal sinus, part of which turns back over the ventricle, but the main sinus is directed forward (fig. 5, b). At its beginning, this is held between the paired gono-pericardial canals, and in front, between and slightly above the paired gonads. The dorsal sinus finally leads into the cephalic sinus which extends towards the head region, above the atrium.

The pericardium (pl. 15, 1; figs. 4, i; 5, e) is an exceedingly spacious chamber. Both the auricle and ventricle adhere tightly to the pericardial wall with their mid-dorsal side and do not fill the chamber. The anterior elongation of the pericardium rapidly decreases in calibre and becomes bipartite medianly by the first course of the dorsal sinus, to form a pair of canals. These are the above-mentioned gono-pericardial canals (pl. 15, b; fig. 5, c) which communicate in front with the cavity of the gonads.

There is a pedal sinus (figs. $1, \mathrm{e} ; 4, \mathrm{f}$ ) which runs dorsally along the whole length of the pedal groove. No direct connection is formed between the pedal sinus and either the cephalic sinus or the caudal sinus, except for the agency of a lacunar system at the points of contact. Lastly I found a large lacuna around the salivary glands.

\section{Reproductive System}

Epimenia verrucosa, like other species of the neomeniinan solenogastres, is hermaphrodite. The gonads (figs. 3 , e; 5 , a) are 
made up of a pair of elongated canals which lie above the midgut, just below the integument. These are connected with the pericardium by means of the gono-pericardial canals.

The gonoducts are as usual differentiated into an upper and a lower portion. The upper gonoducts (figs. $4, \mathrm{~g} ; 5, \mathrm{k}$ ) originate from the postero-lateral corners of the pericardium, as comparatively small canals with a highly folded epithelium. These pass
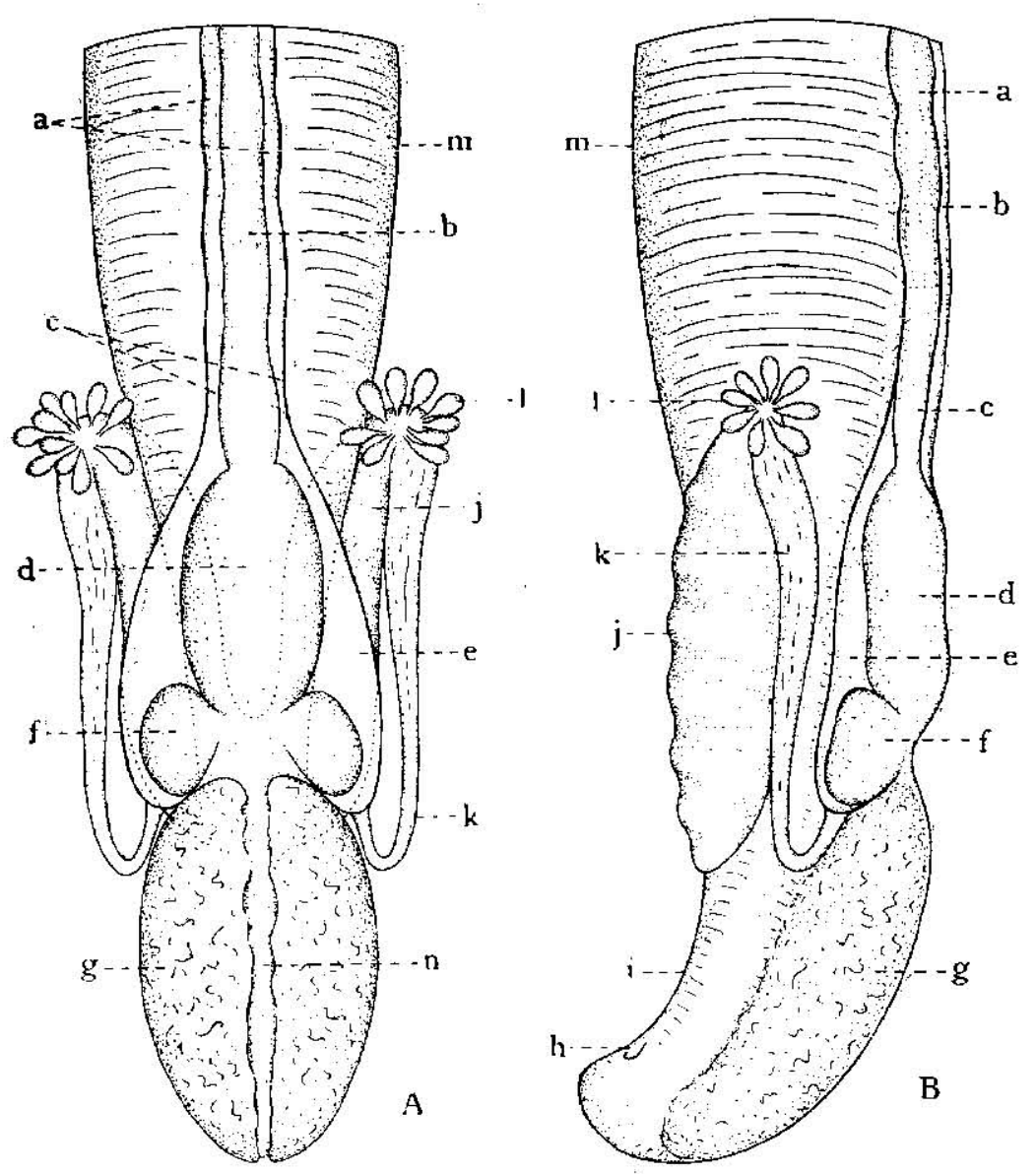

Fig. 5.-General anatomy of caudal visceral organs $(x 6)$. A. Dorsal view. B. Lateral view. a. gonads, b. dorsal sinus, c. gono-pericardial canals, d. ventricle, e. pericardium, f. auricle, g. dorsal cloacal chamber, h. cloacal opening, i. cloaca, j. lower gonoduct, k. upper gonoduct, 1. spermathecae, m. rectum, n. caudal sinus. 
forward, with gradually increasing calibre, to about the level of the anterior wall of the pericardium. There they make an abrupt turn, receive ductules from the spermathecae, and continue posteriorly into the lower halves of the gonoducts. The spermathecae (fig. 5,1$)$ are pear-shaped follicles which range from 7 to 20 in number in different specimens.

The lower gonoducts (pl. 15, j; figs. 4, d; 5, j) consist of welldeveloped mucous glands which are much broader than thick, and lie obliquely applied to the lateral ventral sides of the rectum. Their walls develop a series of 6-7 transverse cushions, which, in turn, give rise to fine longitudinal folds on the internal surface. Posteriorly the gonoducts meet each other to form a short common duct which opens (pl. 15, f) medianly through the ventral cloacal wall at about half-way of the length of the cloaca.

\section{B. TOPOGRAPHIC HISTOLOGY}

\section{Hypodermal Papillae}

The integument of most solenogastres is characterised by the thick development in it of so-called hypodermal papillae. Their shape and constitution are not always the same in the known species, but in nearly all cases the distal swollen end of the papillae reveals a highly vacuolated picture in preserved material. A number of divergent hypotheses have hitherto been proposed, different writers suggesting that the physiological function of the papillae might be excretion, secretion, or tactile sense (see HoffMANN 1929, p. 27). Unfortunately none of these suggestions has ever been confirmed by means of experiments on living specimens, so that the question as to which function is performed by the papillae or what is the real property of them, is still unsettled.

In Epimenia verrucosa, the hypodermal papillae are differentiated into two types: the pigmented papillae and the glandular papillae. Both these originate in the hypodermis and extend to the outside for a distance of about $400-600 \mu$ according to the size of the individual. A thick cuticle (fig. 6,1 ) is secreted by the hypodermis, and below the free surface of this the apices of the papillae are hidden. Outside the hypodermis a considerable number of spiculose matrices (fig. 6, f) stand out at various heights 


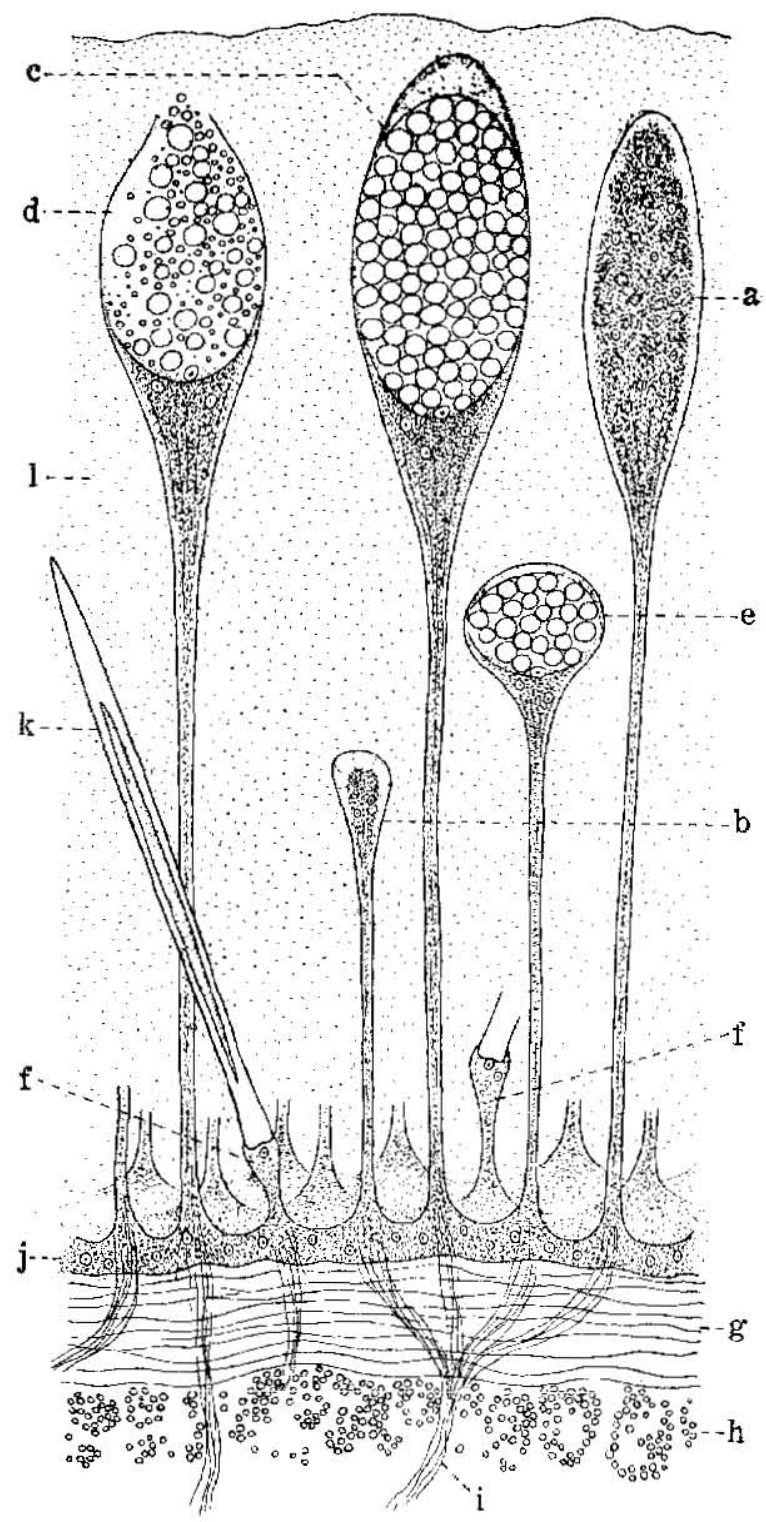

Fig, 6.-Part of a vertical section of the integument, at the spot of a coloured marking, half diagrammatised. Drawn from life $(\times 250)$. a. pigmented papillae, $b$. the same, in younger stage, c. glandular papillae, d. the same, the secretion being discharged by the action of alcohol, e. the same, in younger stage, f. spiculose matrix, g. subcutaneous circular muscles, h. subcutaneous longitudinal muscles, i. mesenteric muscle fibres, j. hypodermis, k. spicule, 1. cuticle. 
and run in different directions. The hypodermis itself (fig..6, j) consists of low columnar cells heavily packed with dark brown pigment granules.

\section{Pigmented Papillae}

These (fig. 6, a-b) are widely distributed in countless numbers almost throughout the integument, and thus constitute practically a thick layer of papillae overlying the hypodermis. Each papilla has a slender stalk, and distally it is more or less inflated. A number of nuclei are located in this inflated portion, but they are almost entirely obscured from sight by a considerable accumulation of pigment granules. This accumulation of pigment continues down the stalk of the papilla as well.

The pigment granules are from dark to blackish brown in colour. They can hardly be extracted by ether, and are well preserved in alcohol, formalin and other fixatives for ordinary histological use. They are naturally considered to be some melanin substance.

\section{Glandular Papillae}

The living animal exhibits coloured markings on a dark brown background. This dark brown colour is evidently due to the melanoid pigment granules which are in the hypodermis and pigmented papillae and are seen through the transparent cuticle. The cuticle is practically colourless. The coloured markings are yellow in some specimens, and vary from greenish to blue in other specimens (see BABA 1939, pp. 37-38, 41). When a vertical section of a bit of fresh integument is made through the coloured markings, there may be seen in these restricted areas a thick aggregation of specialised glandular papillae (fig. 6, c-e). Their bulbous cap is more marked than that of the pigmented papillae. Interiorly it consists of a large cap-cell sustained by fused stalk-cells (see BABA 1938, p. 27). The cap-cell is filled with prominent spherical granules. In a transmitted light the granules are almost colourless or very faintly tinted vermilion, but when seen by reflected light, they show varieties of colours from yellow, or greenish, to blue, according to different individuals. The various colours of the integument are thus caused by the colouring granules contained in the glandular papillae. The papillae contain also a large 
amount of melanoid pigment granules below the cap-cell and in the stalk portion.

On slight application of a sharp dissecting needle to the surface of the coloured markings, a stream of milky and exceedingly viscid secretion passes out of the papillae by rupture of the apical wall of the bulbous cap.

The rudiments of the glandular papillae are recognisable first on the cephalic and caudal segments, a short while later on the trunk segment of the youngest trochophores (see BABA 1938, p. 23). At this stage the secretory granules filled in the cap-cell are colourless and opaque white when seen massively in a reflected light. No pigmented papillae are yet formed anywhere. 'During metamorphosis, the cephalic and caudal papillae disappear owing to the entire degeneration of the corresponding segments, so that only those papillae which have remained on the trunk continue development in later stages.

All the hypodermal papillae and spiculose matrices are each supplied with a moderate number of finest muscle fibres. These fibres run up the whole length of the stalk portion, and in the case of the hypodermal papillae they pass directly into the inflated apical cap. Proximally the fibres extend below the hypodermis and into the underlying muscle layers, and are collected there into more marked muscle bundles (fig. 6, i). The muscle bundles thus formed serve as mesenteric muscles which fasten the outer wall of the digestive tract to the integumental hypodermis.

\section{a. Action of Various Reagents on the Secretory Granules}

The following experiments were carried out with the purpose of testing the properties of the secretory granules contained in the cap-cell of the glandular papillae.

i. Alcohol and Distilled Water: In fresh material the granules appear to be of homogeneous consistency. By the addition of such reagents as alcohol (70-95 per cent.) and distilled water, however, the granules split instantly into finer granulations (fig. 6, d). They are then dissolved and entirely extracted out of the capcell. Boiled water does not coagulate the granules.

ii. Formalin, Bormn's Fluid, and Flemming's Solution: These 
cannot preserve the granules, the latter being gradually destroyed and lost within one hour. The cap-cell becomes empty, except for a fine protoplasmic network.

\section{b. Vital Staining}

Free-hand sections of fresh integument were submerged in dilute solutions $(1 / 100,000)$ of methylene blue and neutral red for about half an hour, and then subjected to examination. These dyes have great affinity for the granules which are stained vivid red with neutral red, and blue with methylene blue. The nuclei remain unstained.

\section{Pedal Gland and Prepedal Cavity}

ODHNER called attention to the fact that in Alexandromenia crassa, the cells constituting the pedal gland are "vacuolated and distinctly show a kind of intracellular lumen appearing in their efferent ductules as seriate vacuoles"; a feature which reminds one of the excretory function of these cells (see ODHNER 1921, pp. 24, 71-72; HofFManN 1929, p. 94).

In Epimenia verrucosa, the pedal gland (pl. 14, i) is found as a voluminous opaque white mass. It surrounds the dorso-lateral walls of the prepedal cavity, and spreads out towards the floor of the foregut. The pedal gland is made up of flask-shaped elements thickly crowded together. The neck of the flask is exceedingly elongated into a fine efferent ductule which opens intercellularly through the epithelium of the prepedal cavity. The distal bulbous portion consists of compound cells. In a fresh condition these cells are filled with colourless transparent granulations. I have made a series of paraffin sections of the pedal gland. When treated with dilute basic dyes, the gland-cells stain metachromatically, showing that their secretion is exclusively mucous. There is practically no evidence of the excretory vacuoles being discharged by the cells of the pedal gland.

The prepedal cavity (pl. 14, 1) is linear when closed. But in the living state it may often be expanded into a rhomboid or even circular disk (see BABA 1939, p. 37, fig. 1, B). The anterior one-fifth of the length of the prepedal cavity is invaginated dor- 
sally and to a less extent anteriorly, and develops there an evenwalled arcuated sinus. The remaining portion is occupied by a delicate tongue-shaped structure. This extends in front to cover partially the entrance of the sinus. The shape of the tongue may vary, but as a rule this tongue has longitudinal folds on the posterior arcuated surface. The excessive inflow of blood into the region of the prepedal cavity pushes forward the whole organ ventrally. It also causes turgescence of the tonguc in various ways. The prepedal cavity then assumes the appcarance of a produced sucking disk.

The prepedal cavity is lined with a single layer of columnar epithelium which is thickest on the tongue and thinner towards the sinus. The whole surface bears a thin cuticle and strong cilia.

The pedal gland continues backward in two elongated stripes all along the peral groove.

The foot is extremely narrow, so that it can hardly be used for creeping. When Epimenia crawls up the glass surface of an aquarium, the locomotion is performed by a gradual snail-like sliding of the ventrai body-surface. A fine thread of mucus is secreted from the pedal groove, which easily clings to any object. The expanded prepedal cavity can also be used as a light sucker.

\section{Epithelia of the Digestive Tract}

1. Atrial Epithelium, Foregut Epithelium

The epithelium is of high columner form (see fig. 7). The cilia on the free surface are short with their basal two-thirds entirely embedded within a thick cuticle. The exposed part of the cilia is more or less cuticulated, so that there can hardly be any recognisable ciliary movement throughout the surface of the atrium and foregut.

\section{Pharyngeal Epithelium}

The general structure is much as in the preceding, but there are diffuse subepithelial glands (fig. 7, d) which discharge their contents into the pharyngeal lumen. Each consists of a small 
flask-shaped cell. The nucleus is basal. The efferent duct passes among the epithelial cells. In a fresh condition the gland-cells are packed with colourless transparent granules.

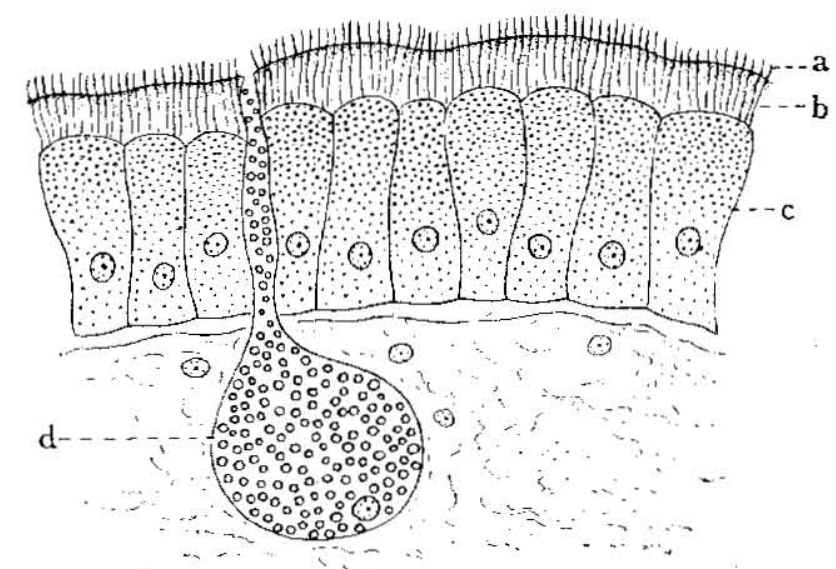

Fig. 7.-Pharyngeal epithelium $(\times 900)$. a. cuticulated cilia, b. cuticle, c. epithelial cells, d. subepithelial gland-cell.

i. Mucus Test: In sections the pharyngeal glands do not stain metachromatically with basic dyes. This shows that the secretion is far from being mucous.

ii. Acid Test: No positive results are obtained by congo red, the granules staining normally with this dye. The distilled water extract of the pharyngeal wall (including the gland-cells) is approximately neutral ${ }^{12}$. The granules of the pharyngeal glands must then b'e some digestive ferments.

3. Dorsal Midgut Epithelium, Rectal Epithelium, and Cloacal Epithelium

Here the epithelium is cuboidal or high columnar in shape. It is non-cuticulated, but has very long cilia on the free surface. At the dorsal cloacal chamber the epithelium markedly increases in thickness. There is no formation of epithelial gland-cells as recorded from various other types of the solenogastres (cf. HoFfMANN 1929, pp. 33-34).

1) $\mathrm{pH}=6.8$; measured through the kindness of Dr. T. Ucus:, Professor in the Nagasaki Medical College. 
4. Nature of the Pigment Granules contained in the Epithelia of the Digestive Tract

Faintly yellowish protoplasmic granulations are contained throughout the epithelia, giving the latter a hue varying from ashy yellow to orange in different individuals. The experiments show that the colouring matter is distributed in the periphery of the granulations; and that it is lipoid in nature is seen from the following facts: (1) The colouring matter is blackened by osmic acid ( 2 per cent.). (2) It can be extracted by ether and other fat-solvents in the form of droplets which stain red with Sudan III.

\section{Salivary Glands}

1. Salivary Duct

The lining epithelium of the salivary duct is thrown into longitudinal and finer tangential corrugations. Its free surface is covered by a colourless homogeneous layer, moderate in thickness (fig. 8, c). What the nature of this formation is cannot be easily determined. It looks like a cuticle but has a special affinity for

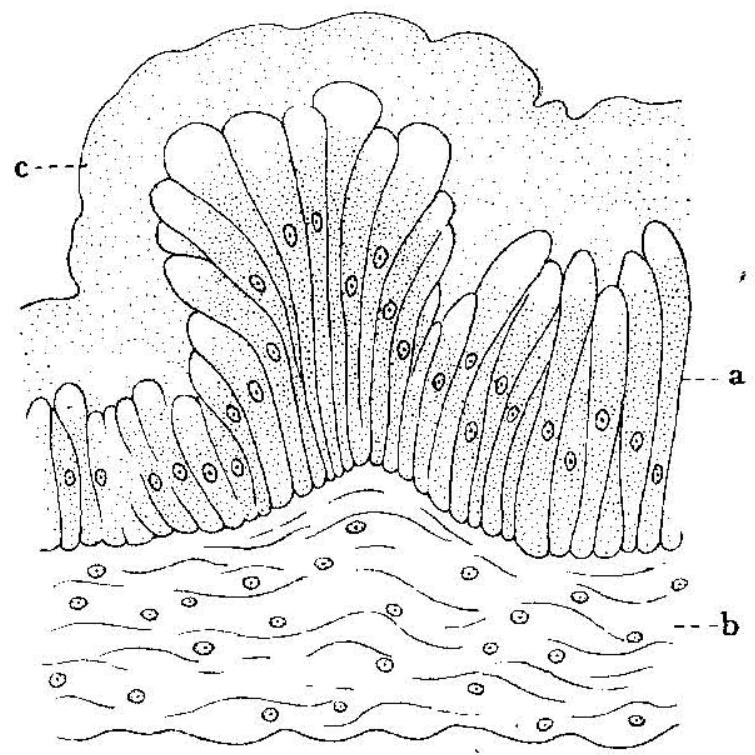

Fig. 8,- Part of a transverse section of the salivary duct $(\times 900)$. a. epithelial cells, b. muscular wall, c. covering layer. 
DELAFIELD's haematoxylin. It does not react to specific mucus stains. It can only be said that the present formation is due to secretion from the underlying epithelium. The individual epithelial cells are of high columnar form with clear colourless granulations. When these latter are exuded the distal end of the cell takes a more or less vacuolated appearance (fig. 8, a).

The salivary duct has a thick coat of muscular fibres which run irregularly in all directions. Yellowish pigment granules are included within this muscular coat, the variable amount of which gives to the whole salivary duct colours ranging from yellowish to orange.

\section{Glandular Portion}

The main body of the gland debouches into the duct lumen through a papillar projection. External to the gland there is a delicate muscular coat of interwoven circular and longitudinal fibres. The circular fibres are diffuse, but the longitudinal ones have a tendency to collect into bundles. Contraction and constriction sometimes take place on the surface of the gland, apparently helping the discharge of secretion from the glandular tissue. The fresh gland appears opaque white. Here again the pigment granules are included within the muscular coat, but their distribution is not so marked as in the duct.

The secretory wall of the gland is very much thickened. It consists exclusively of tall, cylindrical gland-cells packed, when fresh, with colourless, prominent granules (fig. 9). No supporting elements are found anywhere. The secretion from the gland-cells is a milky white, viscous fluid.

On application of intravitally staining methods, the secretory granules quickly stain red with neutral red, and blue with methylene blue. In paraffin sections these granules are liable to take eosin. The distilled water extract of the salivary gland shows a faint trace of acidity ${ }^{12}$.

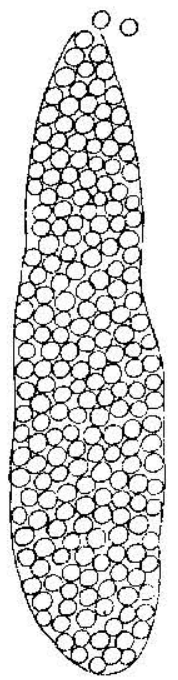

Fig. 9.--Freshly isolated cell of the salivary. gland $(\times 700)$.

1) $\mathrm{pH}=6.3$; determined by $\mathrm{Dr}$. T. Ucrrso. 
The salivary gland passes posteriorly into a short flagelliform termination with no marked glandular tissue whatever.

\section{Villous Cells of the Midgut}

Recent investigations have required much amendment to our coventional conceptions regarding the physiology of the so-called molluscan 'liver', though this latter may manifest diverse func-

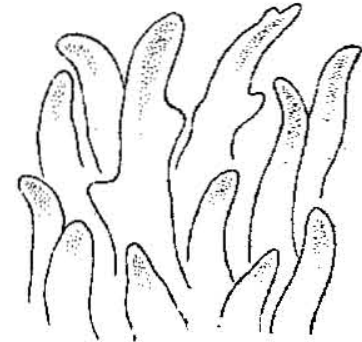

Fig. 10. - Villi, drawn from life. tions in different types of animals. Thus in Ostrea and other pelecypods, the liver, better called digestive diverticulum, possesses the power of taking in food stuffs and digesting them intracellularly (YoNGE 1926-27). In herbivorous gastropods such as Tethys and Haliotis there is indication of the production of a copious supply of ferments for extracellular digestion (EALES 1921, CROFTS 1929). An additional case of intracellular digestion is recorded for Haliotis (CROFTS 1929). In snails (CuínOT 1892), nudibranchs (Hecht 1895) and others ${ }^{1)}$, however, part of the liver cells appear to take part in the elimination of waste matters.

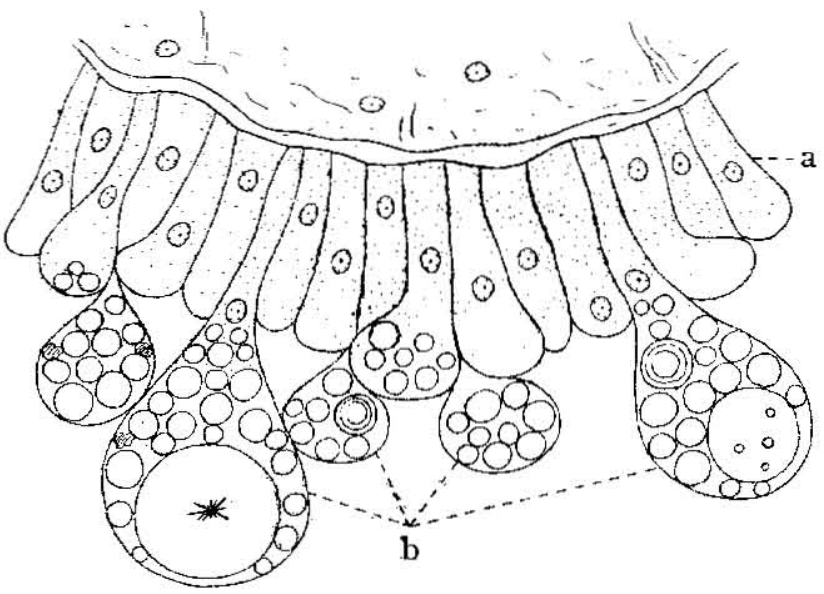

Fig. 11.-Epithelial cells of the villi $(\times 1200)$. a. youngest cells, b. flask-shaped gland-cells.

1) Pecten (Dakin 1909), Okadaia (Bara 1937). 
In Epimenia, the villi of the midgut wall represent the 'liver' in other molluses, and constitute one of the most important structures in connection with the absorption (more broadly digestion) and excretion functions of this animal. They are usually of a simple digit-shape, but sometimes with short branches on the surface (fig. 10). The colour varies with the pigment granules contained, from orange-yellow, or deep reddish, to various tones of ashy yellow. These colours shine through the integument and to some extent affect the general ground-colour of the body.

The epithelial cells of the villi are seen in various stages of development. The youngest cells (fig. 11, a) are of tall columnar form with their nuclei situated near the base or midway between the base and the free end. As they gradually develop, the distal half commences swelling, and eventually they are differentiated into flask-shaped glandcells (fig. 11, b). The gland-cells thus formed are held among the general epithelium by their elongated neck, but are apt to fall off quite easily. The bulbous portion of the glandcell is free and directly abutting on the lumen of the midgut. The interior of the villi is occupied by lacunose connective tissue. In a fresh condition the villi can perform contraction, extension, or gentle swinging in all directions, presumably by means of the mesenteric muscle fibres which connect the villi to the integumental hypodermis.

When the animal is in a good nutritive condition, the full-grown cells of the villi are always packed with ferment granules (fig. 12, g).

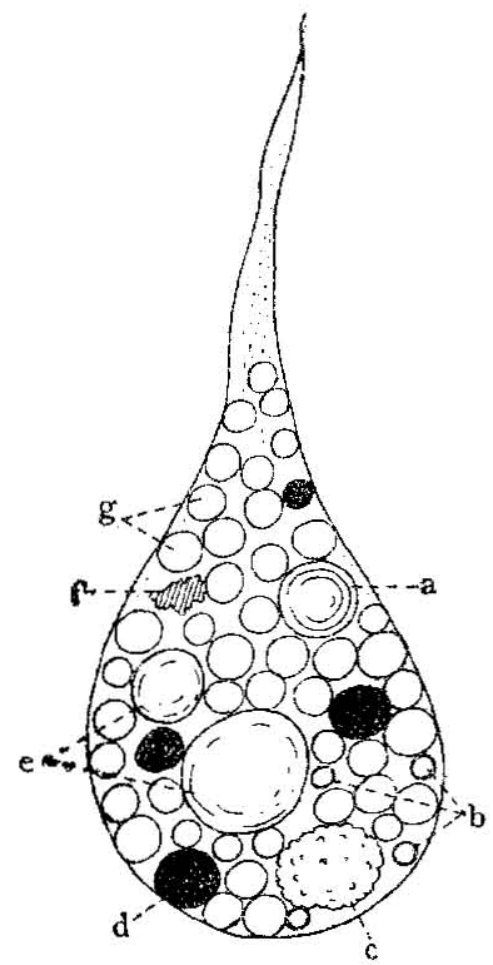

Fig. 12.-Freshly isolated gland-cell of the villi, half diagrammatised ( $\times 1300$ ). Taken from a specimen in which black ink and carmine particles have been injected. a. yellow globule, b. oil droplets, c. pigment granule, d. ingested black ink, e. ingested food substances, f. ingested carmine particle, g. fer. ment granules. 
In consistency these granules are homogeneous. They are clear and colourless, in some cases faintly tinged with yellow. The cytoplasm is also clear and homogeneous, and is defined externally by a delicate protoplasmic membrane. The nucleus lies in the proximal portion at various heights of the neck.

The extract of the villi by a small amount of distilled water shows a faint trace of acidity".

Food substances, pigment granules, oil droplets or metabolic end-products are also included within the villous cells (see fig. 12), but the details will be given in later pages.

\section{Action of Various Reagents on the Villous Cells and their Ferment Granules}

The following experiments were carried out in all cases by adding various reagents to microscopic preparations of the fresh villous cells.

i. Alcohol, Formalin, and Sublimate: By addition of alcohol (70 per cent., 95 per cent.) part of the granules may be destroyed, but the rest are well preserved in the cell. Formalin (4 per cent.) and corrosive sublimate (saturated in sea-water) are also good fixatives for the granules and for the cell-body as well.

ii. Dilute Acids (5 per cent. $\mathrm{HCl}, 5$ per cent. Acetic Acid), Bouin's Fiuid, and Flemming's Solution: These affect the granules which are instantly swollen and then dissolved. The cell undergoes swelling, but not destruction. For detailed histological preparations Bouin's fiuid and FLEMMING's solution cannot be recommended as fixatives.

iii. Osmic Acid: With osmic acid ( 2 per cent.) the cell is preserved as it is, but most of the granules are dissolved. No black reaction was observed on the surface of the granules.

iv. Dilute Alkalis ( 5 per cent. $\mathrm{NaOH}, 5$ per cent. $\mathrm{KOH}$ ) : These cause the cell and granules to swell immediately and then to dissolve.

v. Distilled Water: As a result of absorption of distilled water the cell swells. The granules are also affected, and the greater part of them are destroyed forming finer granulations.

vi. Hypertonic Salt Solution: The water is abstracted from

i) $\mathrm{pH}=6.3$; determined through the hand of Dr. S. Hibusin, Lecturer in the Nagasaki Medical College. 
the cell in hypertonic salt solution which has an osmotic pressure twice or thrice that of sea-water. The cell shrinks markedly and the granules run together.

\begin{tabular}{|c|c|c|c|c|c|}
\hline Reagents & $\begin{array}{l}\text { Cell-body } \\
\text { Granules }\end{array}$ & Villous cells & Amoebocytcs & Erythrocytes & Platelets \\
\hline \multirow{2}{*}{ Dist. water } & Cell & ++ & ++ & +++ & ++ \\
\hline & Gr. & +++ & +++ & + & + \\
\hline \multirow{2}{*}{ Alcohol } & Cell & + & + & + & + \\
\hline & Gr. & + & + & + & + \\
\hline \multirow{2}{*}{ Formalin } & Cell & + & + & + & + \\
\hline & Gr. & + & + & + & + \\
\hline \multirow{2}{*}{ Sublimate } & Cell & + & + & + & + \\
\hline & Gr. & + & + & + & + \\
\hline \multirow{2}{*}{$\begin{array}{l}\mathrm{NaOH}, \\
\mathrm{KOH}(5 \%)\end{array}$} & Cell & +++ & +++ & +++ & $t+t$ \\
\hline & Gr. & +++ & + & +++ & + \\
\hline \multirow{2}{*}{$\begin{array}{l}\mathrm{HCl}, \\
\quad \text { Acetic }(5 \%)\end{array}$} & Cell & ++ & ++ & ++ & ++ \\
\hline & Gr. & +++ & +++ & + & +++ \\
\hline \multirow{2}{*}{ Bouin } & Cell & ++ & ++ & ++ & $t+$ \\
\hline & Gr. & ++ & +++ & + & +++ \\
\hline \multirow{2}{*}{ Flemming } & Cell & ++ & ++ & ++ & ++ \\
\hline & Gr. & $+t+$ & $+t+$ & ++ & ++ \\
\hline \multirow{2}{*}{ Osmic $(2 \%)$} & Cell & + & + & + & + \\
\hline & Gr. & $+t+$ & ++ & + & +++ \\
\hline
\end{tabular}

Table showing action of various reagents on villous cells and blood cells. Experiments were always made on fresh microscopic preparations. Cells: + fixed, ++ swollen, ++ swollen greatly, +++ swollen and dissolved. Granules: + fixed, +++ swollen and dissolved.

vii. Ether, Chloroform, and Aceton: The granules were not dissolved by any of these fat-solvents.

We may conclude from the above experiments that the ferment granules have comparatively strong resistance to alcohol, 
formalin and sublimate, but are easily destroyed by acidic fixatives and a number of other reagents. There is no positive reaction of fat or lipoid for the granules.

\section{Staining Methods}

The ferment granules of the villous cells stain vividly with intravital methylene blue and neutral red. In sections they show an affinity for eosin.

\section{Amoeboid Behaviour of the Villous Cells; Phagocytosis}

Freshly isolated cells of the villi were kept in a moist chamber and examined at intervals. As isolated they take at first a typical flask-shape (see fig. 12), or more often they are more or less rounded in the medium (sea-water). Within a few minutes there commence viscous outflows of hyaline protoplasm from the surface of some of the cells. These are the so-called pseudopodia

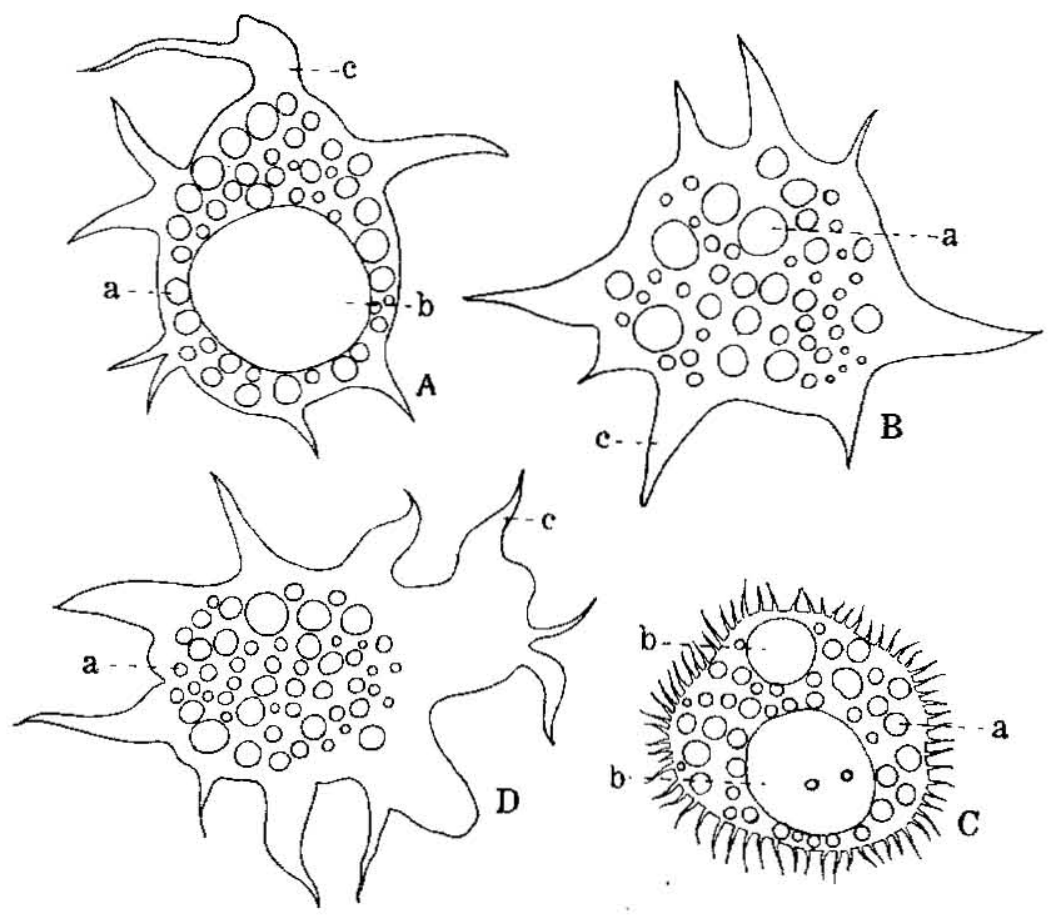

Fig. 13.-Isolated villous cells, showing various changes of form in the living state $(\Varangle 1200)$. a. ferment granules, b. vacuoles, c. pseudopodia. 
Absorption and Excretion in a Solenogastre, Epimenia verrucosa 141

which may be stretched out freely in any direction with continual change of form. After the lapse of thirty to sixty minutes, however, many become fully expanded with a variable number of pseudopodia on their surface, thus assuming entirely the general appearance of an amoeba (fig. 13). The ferment granules and other inclusions are all collected near the centre of the cell. The pseudopodia of the villous cells are usually lobe- or bristle-shaped; infrequently they are ciliform. They usually cover the whole surface of the cell, but sometimes are confined to a small part of it.

When a small quantity of carmine particles are introduced into the medium of the moist chamber, these are ingested
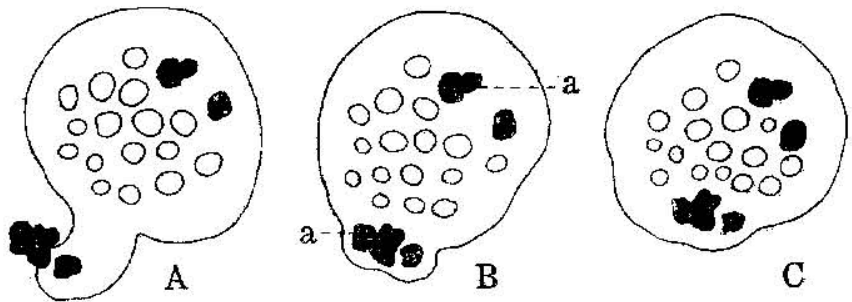

Flg. 14.-Ingestion process by the isolated vilious cells when these are in a fresh condition. a. carmine particles. $(\times 1000)$.

phagocytically by the villous cells (fig. 14). The ingestion takes place at any point of the surface of the cell with which these particles come in contact.

\section{Pigment Granules}

The villous cells of the midgut contain pigment granules. At first sight these latter appear to be exceedingly diverse, but a closer examination shows that they consist of two main types, yellow globules and pigment granules in a narrow sense. The yellow globules (fig. 12, a) are perfectly spherical, 3-7 $\mu$ in diameter and more or less refractive with concentric structural zones. The density of colour ranges from pale yellow to deeper chrome- or orange-yellow. The pigment granules are as a rule finer in size than the yellow globules, but often show a tendency to be packed together (fig. 12, c). The colour is widely divergent: yellow, yellowish green, brown, reddish brown, carmine red, etc. 
The yellow globules are hardly soluble in ether and chloroform and cannot be stained black by osmic acid. On the other hand the pigment granules show positive reactions for lipoid. Thus in fat-solvent reagents, the colouring matter of the pigment granules is extracted as oily drops. It reduces osmic acid and becomes blackened.

A careful identification was made of these two sorts of pigment granules with those colouring the polyps of Nephthya and Dendronephthya which Epimenia attacks. There is adequate reason for believing that the villous cells take up phagocytically the pigment granules and others from the chylified flesh of the victims, and store them for a varying length of time.

\section{Oil Droplets}

In a fresh condition there are small quantity of colourless or slightly yellowish droplets of oil (fig. 12, b) in most of the villous cells. These are distinguished from the ferment granules by their strongly refractive appearance. They become more clearly discernible when the ferment granules are dissolved altogether by the addition of dilute acids or alkalis. For testing the oily nature of the droplets Sudan III and osmic acid were employed, always with positive results.

\section{Food Substances; Vacuole Formation by Intracellular Digestion}

Substances that can be identified as ingested food are found in the cells of the villi when the animal is well fed. These (fig. 12, e) constitute colourless or yellowish, somewhat opaque masses that are usually larger than the ferment granules. Thus the largest ones often occupy the greater part of the mother cells. In their reactions for various dyes and reagents, the food substances do not differ much from the ferment granules.

During ten to fifteen days' starvation of the animal, much of the stored food substances disappears from the villous cells, presumably by intracellular digestion at the expense of ferment granules. The first apparent result is the formation there of small and large vacuoles roughly corresponding to the size of the food substances. A sudden decrease in amount of the ferment granules may also be noticed. 
Absorption and Excretion in a Solenogastre, Epimenia verrucosa 143

\section{Excretory Villous Cells; Concretions and Crystals of Uric Acid}

When the cells of the villi get old and inactive in secretion, their interior becomes occupied by a huge vacuole which pushes cytoplasm towards the periphery of the cell (fig. 15). The ferment
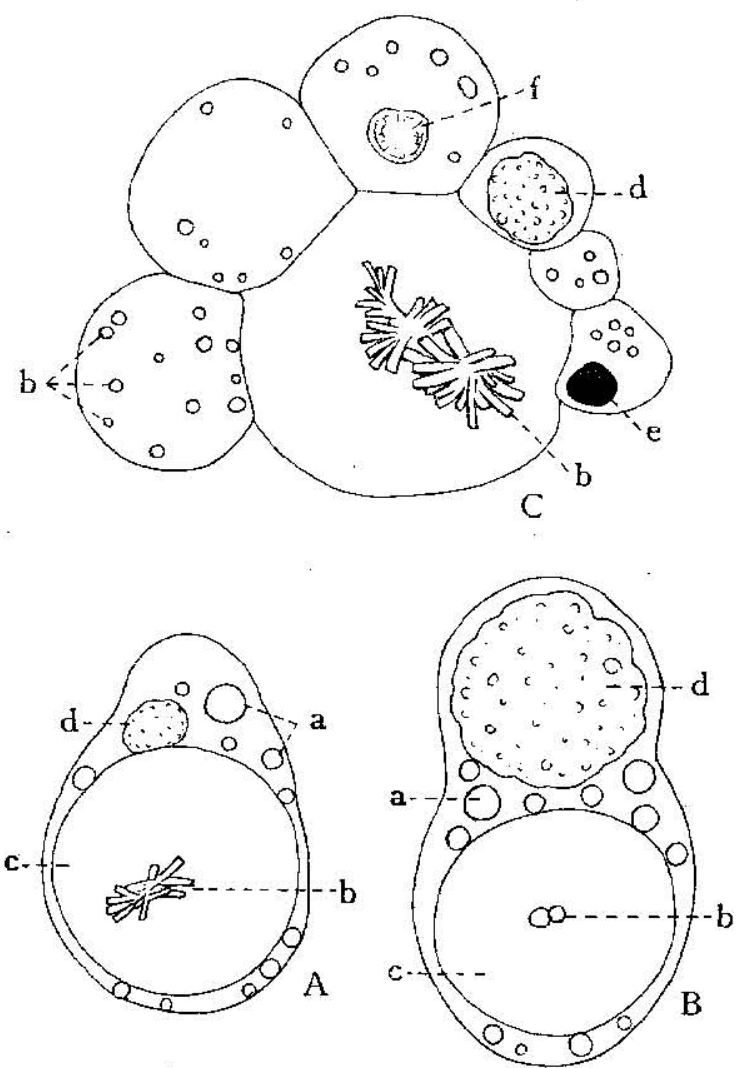

Fig. 15.-Excretory villous cells $(\times 1300)$. Drawn from life. a. ferment granules, b. concretions and crystals of uric acid, c. vacuoles. d. pigment granules, e. ingested black ink, f. yellow globule.

granules are scarce or have disappeared altogether. The stored pigment granules remain intact for the most part, but some lipoid granules are destroyed and faded away, perhaps a sign that they have undergone digestion. 
Moreover there are a varying amount of metabolic endproducts represented chiefly by the uric acid concretions and crystals, in the liquid inclusion of the vacuole (see fig. 15). They

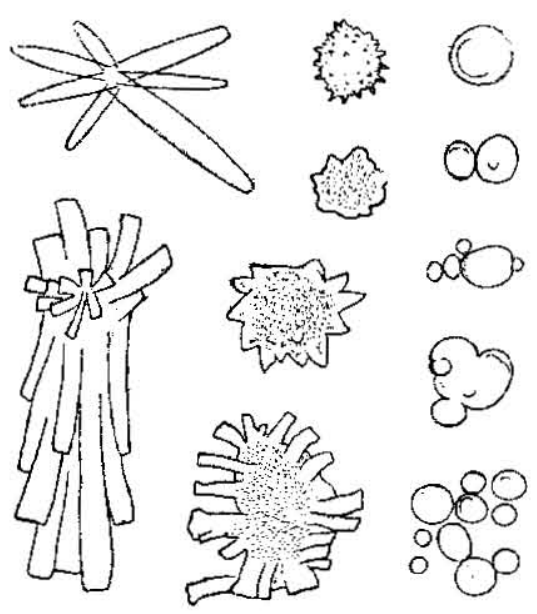

Fig. 16.-Concretions and crystals of uric acid, taken from living specimens. are dull ashy or faintly yellowish, $0.5-5 \mu$ in size, and take a large variety of forms: rounded granules, irregular granules, fused or compound granules, irregular masses, irregular comfits, fused comfits, or very fine comfits, etc. (fig. 16). These formations are soluble in dilute alkalis $\mathrm{NaOH}$, $\mathrm{KOH})$ and in concentrated sulphuric acid; but practically insoluble in alcohol, ether and cold water.

The vacuolated cells thus loaded with uric acid, are removed from among the active epithelium of the villi, and shed

into the lumen of the midgut. Here they assume a perfectly spherical form measuring about $10-25 \mu$ in diameter, are more or less gathered together (see especially fig. 15, C), and finally come to be expelled to the exterior as an excretion.

\section{Blood}

Our present knowledge concerning the histology and physiology of the blood in the solenogastres is very limited and incomplete. But roughly speaking, it has generally been accepted that the blood is red-coloured, containing one or two types of form-elements such as erythrocytes and amoebocytes (see HofFMANN 1929, pp. 113-114). According to my observation there is an additional type, viz. platelets, in the blood of Epimenia. Of these three, the most intimately related to the functions of absorption and excretion are the amoebocytes. The erythrocytes are haemoglobin-carriers. The function of the platelets is entirely unknown. In number, the erythrocytes are the largest, but the amoebocytes and platelets are also abundant. The blood-plasma, when freshly collected and 
freed from corpuscles, is clear and perfectly colourless. It remains fluid on exposure to air or after being heated to over $80^{\circ} \mathrm{C}$. It is stated that the blood of the Chaetodermatidae coagulates by addition of acetic acid (cited from HorFMANN 1929, p. 113), but such is not the case in Epimenia blood.

The blood corpuscles are distributed in the heart, sinuses, and lacunae in the connective tissue between the integument and the digestive tract, an especially large number being normally present in the distal portion of the villi. There are none in the pericardial chamber.

\section{Amoebocytes}

The amoebacytes of the molluscan blood have long been an attractive object for many investigators. When we refer to the latest work of TAKATsuki (1934), the Ostrea amoebocytes are said
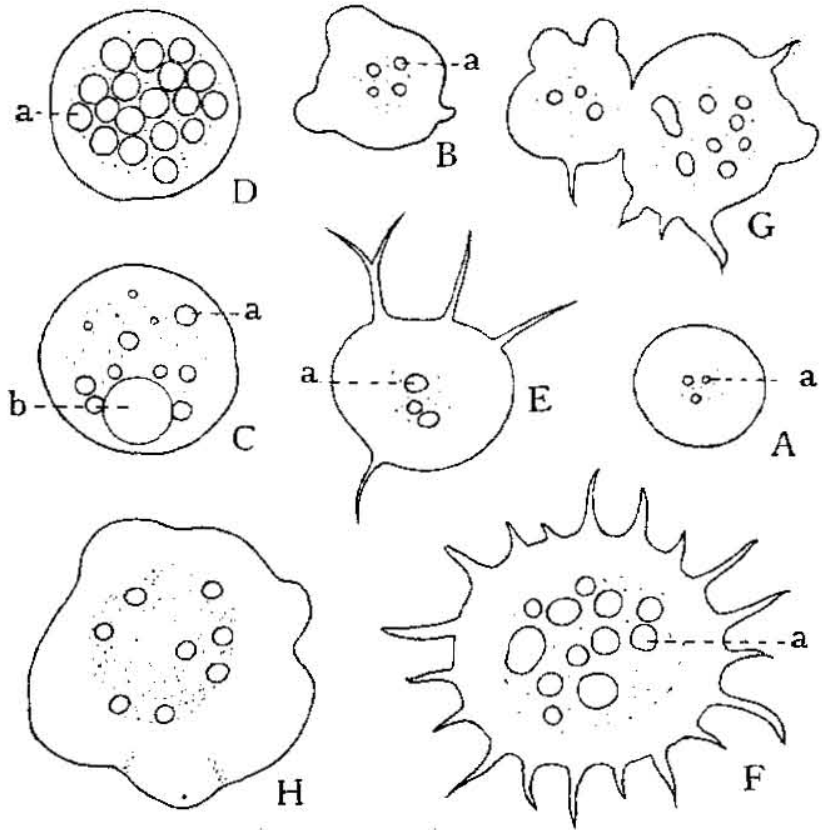

Fig. 17.-Amoebocytes $(\times 1800)$. A-F. Various forms of the living amoebocytes, a. ferment granules, b. vacuole. G. Bipartiting amoebocyte, H. An amoebocyte acted upon by distilled water. 
to take part in the absorption by phagocytosis, in the intracellular digestion by the aid of the ferment granules contained, and in the elimination of waste or objectionable matters. It is also noted that there is a complete oxidase system due to the ferment in the amoebocytes.

In Epimenia, the amoebocytes constitute clear, colourless corpuscles measuring usually $10-15 \mu$ in diameter (fig. 17). The cytoplasm is homogeneous, but towards the centre it shows a finely granulated appearance. A number of granules that can be identified with the ferment granules of the Ostrea amoebocytes are included in the cytoplasm. When fresh these are colourless or faintly yellowish, and greatly vary in size and number. The amoebocytes are characteristically amoeboid, continually changing their form, and are capable of extending lobe- or bristle-like pseudopodia. In very rare cases the amoebocytes are seen clinging together by their pseudopodia, but the property of forming a 'clump' is not so marked in Epimenia as in Ostrea and other molluscs. Pigment granules are entirely absent. The food substances and vacuoles very rarely occur in the amoebocytes, and uric acid formation was never found.

\section{a. Action of Various Reagents on the Amoebocytes and their Granules}

i. Alcohol, Sublimate, and Formalin: The cell and granules are well preserved in these fixing fluids.

ii. Dilute Acids ( $\mathrm{HCl}$, Acetic Acid), Bourn's Fluid, and FlemMing's Solution: By these the cell and granules swell instantly, and the latter tend to dissolve altogether. The cytoplasm becomes then foamy in appearance.

iii. Osmic Acid: The cell is well fixed by osmic acid, but the granules are immediately dissolved. No positive colour reaction for lipoid was observed on the granules.

iv. Dilute Alkalis $(\mathrm{NaOH}, \mathrm{KOH})$ : The action of alkalis is more or less characteristic. The cell is entirely dissolved immediately after swelling, but the granules remain intact.

v. Distilled Water, Hypertonic Salt Solution: By addition of distilled water, the amoebocyte swells greatly, the cytoplasm is clearly differentiated into a granular endoplasm and a hyaline, 
Absorption and Excretion in a Solenogastre, Epimenia verrucosa 147

fluidal ectoplasm, and the external protoplasmic membrane becomes more or less folded by subsequent shrinkage of the cell (fig. 17, H). Finally there ensues entire disappearance of the granules contained.

In the hypertonic salt solution the cell remains shrunk.

vi. Ether, Chloroform, and Aceton: The granules were not abstracted by these fat-solvent reagents.

\section{b. Vital Staining}

The granules show an affinity for intra-vitam methylene blue and neutral red.

\section{Erythrocytes}

The erythrocytes are quite peculiar, showing the general shape of a microscopic motor-boat, usually upside down (fig. 18). The cabin or the cell-body is swollen and almost vesicular, and con-
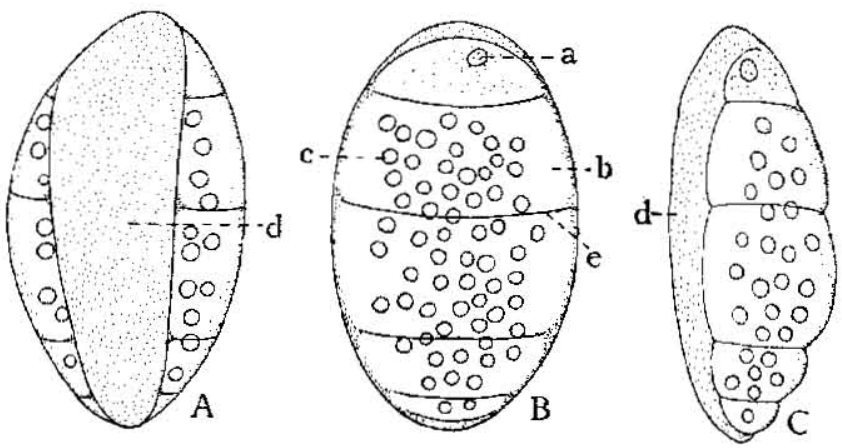

Fig. 18.-Living erythrocytes $(\times 2000)$. A-B. from upper or lower surface, C. from lateral side. a. nucleus, b. vesicle, c. pinkish yellow granules, d. lamella, e. protoplasmic thread.

tains a varying number of yellowish to pinkish yellow granules. The pinkish red colour of the blood in Epimenia is due to the erythrocytes seen in a thick mass. On one side of the vesicle there is a thin lamella. This is oblong or rhomboidal, or more often wedge-shaped, and is slightly yellowish green in colour. Exceedingly fine threads of protoplasm arise from the borders of the lamella, bridge over the vesicle, and so sustain the vesicle in 
a swollen condition. Often the bridging threads themselves anastomose in a fine network. The stroma in the vesicle is clear and colourless. The nucleus lies at different points of the vesicle. The largest erythrocytes measure from $20-25 \mu$ in length.

The 'large oblong corpuscles' recorded from Proneomenia discoveryi by NIERSTRASZ (1908, p. 7, pl. 2, fig. 26 A) are apparently identifiable with the erythrocytes in question.

No amoeboid change of form was observed on the part of the erythrocytes.

The granules contained in the vesicle take methylene blue and neutral red intravitally. They show no lipoid reaction to osmic acid, nor are they extracted by ether and chloroform. When fixed and mounted, the lamella of the erythrocyte stains red with eosin.

The erythrocytes are well fixed in alcohol, formalin, sublimate and also in osmic acid. But in FLeMming's solution the granules are destroyed and dissolved. In dilute acids ( $\mathrm{HCl}$, acetic acid) and Bouin's fluid the cell swells, and then undergoes violent shrinkage especially at the lamella, but the granules remain intact. The action of distilled water is remarkable and worthy of notice. The vesicle and lamella are at once swollen and dissolved in a clear yellowish spherule which finally bursts open and the
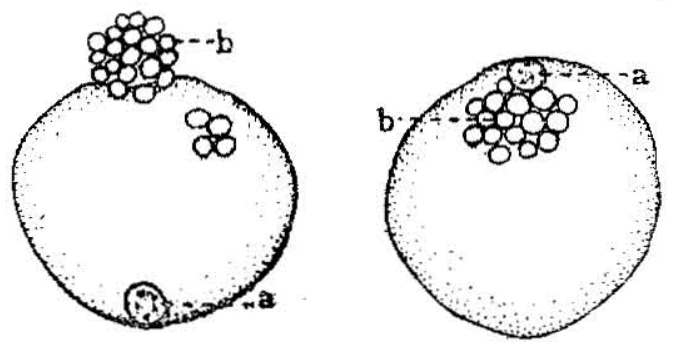

Fig. 19.-Cytolysis of erythrocytes caused by distilled water $(\times 2000)$. a. nucleus, b. pinkish yellow granules.

granules often escape (fig. 19). Alkalis also cause haemolysis: by these the erythrocytes are affected in the manner just described, but the granules disappear entirely.

\section{Blood Platelets}

The platelets are flat, disk-shaped corpuscles. When free in blood or in allied medium they appear as short rods or circular 
or elliptic plates, according as they are seen on edge or from the surface (fig. 20, A-B). The cytoplasm is clear, colourless, and of homogeneous consistency. It contains a large number of granules
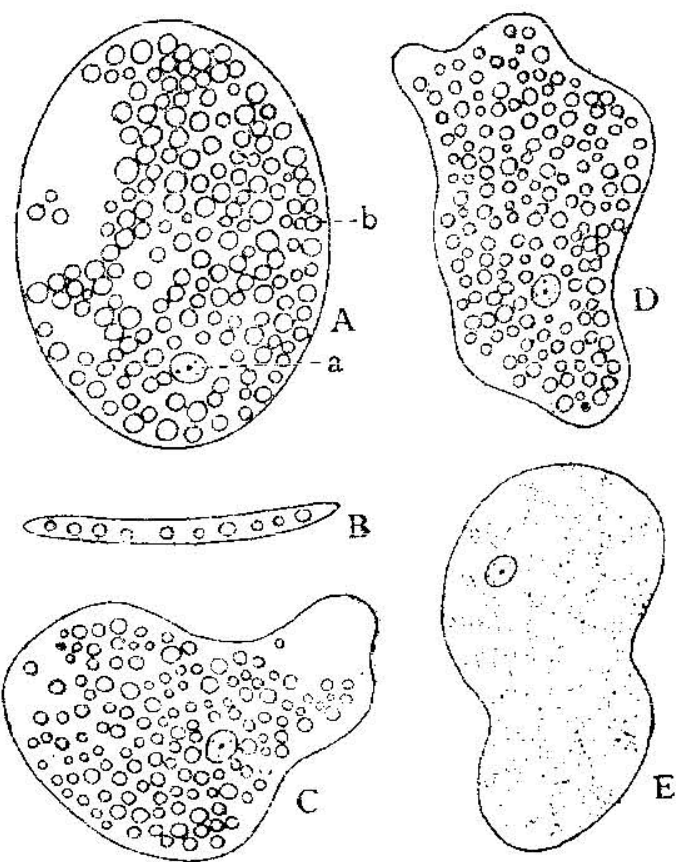

Fig. 20--Platelets $(\times 2000)$. A. living platelet from surface, a. nucleus, b. achromatic granules. B. The same from edge. C-D. Various changes of form. E. Platelet acted upon by acetic acid.

which are also colourless and transparent and vary in size and number. They are evenly distributed or more or less gathered together, and in the fluidal cytoplasm they show a Brownian movement. The periphery of the cell is defined by a delicate protoplasmic membrane. The nucleus is discernible as a compact roundish mass situated at the centre or near one side of the cell. After removal from blood the platelets do not disintegrate, and coagulation of blood never takes place. In length they are about equal to the erythrocytes, but are decidedly larger than the amoebocytes. From these circumstances the platelets of Epimenia may not be properly compared with the cells of the vertebrate blood bearing the same name. Nevertheless the occurrence of platelets as the 
third organised, elements in the blood of the solenogastre is interesting and worthy of notice.

No amoeboid movement is possible for the platelets. But when flowing in stream, they are seen undergoing exquisite change of form (fig. 20, C-D) and thus adapting themselves to pass through any finest space among the tissue elements.

The platelets are as a rule non-pigmented. But in rare cases a small number of pigment granules are included which have the appearance of the pinkish yellow granules in the erythrocytes.

The granular contents of the platelets have a characteristic consistency. They show strictly no affinity for dyes staining intravitally, and are easily dissolved by such reagents as are acidic ( $\mathrm{HCl}$, acetic acid, Boun's fluid, Flemming's solution). By these reagents the cell at first swells and then undergoes violent shrinkage to such an extent that it assumes a decreased spherical or irregularly elliptic outline. During this change the granules cease their Brownian movement and begin to dissolve. As a final result abundant vacuoles arise in the cytoplasm, and the nucleus becomes clearly visible (fig. 20, E). Osmic acid dissolves the granules, but the action is only gradual. On the other hand the platelets are well preserved in alcohol, formalin and sublimate.

THIELE distinguished the blood corpuscles of Neomenia grandis into two types (1894, pp. 238-239, pl. 13, figs. 49-50). The smaller are identified here as the amoebocytes, and the larger, discoid ones, as the platelets.

In alkali solutions the platelet swells and bursts, but the granules are not affected. The action of distilled water is very slight. The cell sometimes swells and becomes rounded by absorption of water, but it does not undergo decomposition, nor is the movement of the granules arrested. In high concentration of the hypertonic salt solution the cell shrinks and the movement of the granules is arrested.

There is no evidence of any oily nature of the granules, as confirmed by the use of osmic acid and fat-solvents.

\section{Epithelia of the Pericardium and Gono- Pericardial Canals}

The lining epithelia consist simply of low columnar cells with short cilia on the free surface. Externally there is a thin 
layer of muscle fibres. No specialised gland-cells are visible anywhere.

The pericardium constitutes, as described previously, a roomy chamber. In mature specimens this is always utilised as a provisional reservoir for sperms and oocytes before these are conveyed to the exterior.

\section{Gonoducts}

\section{Upper Gonoducts}

These are never glandular. The epithelial cells are as usual tall and columnar, and the free surface is covered by long cilia. When fresh, the upper gonoducts appear faintly yellowish, due to the similarly coloured granulations of protoplasm contained in the epithelium. There is a thin external covering of muscle fibres which run irregularly in various directions.

2. Spermathecae

The spermathecae are opaque, and tinged just as in the upper

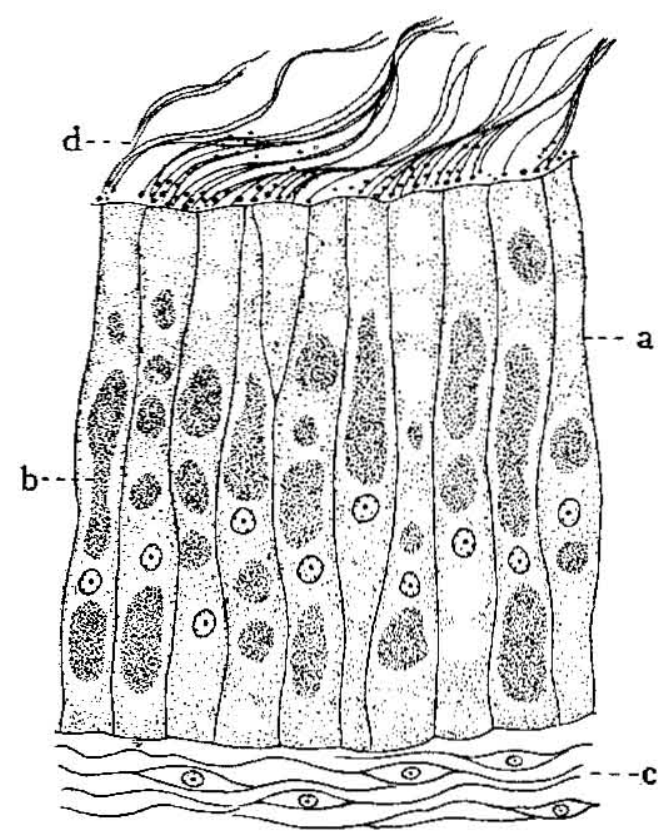

Fig. 21.-Part of the spermathecal epithelium $(\times 800)$. a. glandular epithelial cells, b. secretion, c. muscular wall, d. sperms. 
gonoducts. They have a thin muscular coat as well. But the epithelial cells are very large, being about 3-5 times as high, and are apparently of a glandular nature (fig. 21). The secretions are clear and slightly yellowish. They take faintly eosin in mounted sections. When these are discharged, the cytoplasm presents a highly vacuolated appearance. The nuclei lie at about one-third the height of the cell from the base. In the mature life the sperms are crowded within the spermathecae with their heads directed centrifugally, and thus obscure the presence of cilia on the free surface of the gland-cells. But when the spermathecae are empty due to sexual immaturity of the animal, we can identify long cilia with certainty.

\section{Lower Gonoducts}

There is much discussion as to whether these organs actually take part in the elimination of waste matters as the chiton kidneys do. In the species of the Chaetodermatidae, it is assumed that the lower gonoducts are functional in excretion because the cells found here are low cuboidal and vacuolated, containing something like concretions. But unfortunately there is no experimental proof to support such a view (see HEATH 1911, pp. 39, 54-55, 58, 71; HOFFMANN 1929, pp. 82, 93). In the rest of the solenogastres, the lower gonoducts are specialised entirely as mucous glands, thus leaving hardly any room for postulating an excretory character of these organs.

The lower gonoducts in Epimenia are whitish, and slimy to the touch. The wall is very much thickened. It consists of two main types of epithelial cells: ciliated cells (fig. 22, c) and nonciliated mucous gland-cells (fig. 22, a). The former are of tall columnar shape with nuclei situated at about half the height of the cells and bearing long cilia on the edge. The cytoplasm is finely granulated. The latter are also tall and columnar, but the distal half is more or less swollen. The secretory granules are clear and colourless when in the fresh condition. After preservation they stain erratically with specific mucus stains such as polychrome methylene blue, thionin, toluidin, etc. The nucleus lies high up in the cell. I have carefully examined the entire series of paraffin sections of the lower gonoducts, but no eosinophile albumen-gland was distinguished here (cf. HEATH 1911, p. 150 ; 
1918, pp. 221-222; HofFmanN 1929, p. 86). At the foremost end of the lower gonducts, the lining epithelium becomes non-glandular and directly continues into that of the upper gonoducts. Posteriorly at about the region of the common gonoduct the mucous cells

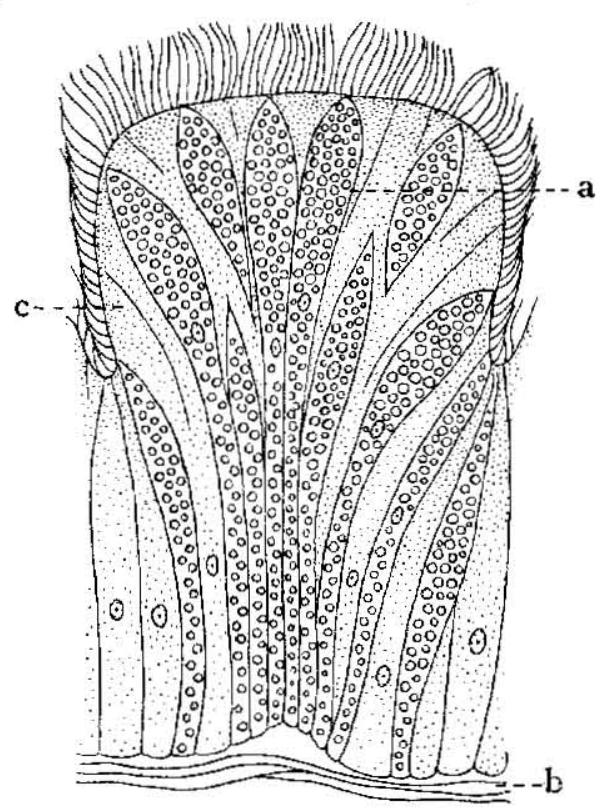

Fig. 22.-Epithelium of the lower gonoduct $(\times 600)$. a. mucous gland-cell, b. muscular wall, c. ciliated epithelial cells.

gradually disappear, and the epithelium consists exclusively of the ciliated columnar cells.

Many times I have collected oocytes while these were being conveyed through the gonoducts or after they have been laid down. During the growth phase the oocytes are attached to the inner walls of the gonads, and are externally covered by a follicle. When full-grown they are freed into the gonad lumens, and gradually come down towards the pericardium where they are provisionally stored. At about the intersection of the upper and the lower gonoducts an egg-capsule is formed round the individual oocytes. This is a delicate but quite resistive membrane which stains red with eosin. A thick coating of mucus is then acquired while in the lumen of the lower gonoducts, and the 
balls so formed are attracted to each other to form a flat eggband. The mucous coating stains metachromatically with basic dyes. The egg-band is immediately conveyed to the exterior, but in some cases it is kept in the cloacal chamber (presumably in the dorsal cloacal chamber) for varying lengths of time, and then it is laid. In this latter case the eggs are reared to about the trochophore stages or further even to the metamorphosed larval stages.

\section{Origin and Development of the Gonoducts}

That the gonoducts first arise in a very early larval stage as a pair of diverticula from the neck of the cloaca, has previously been noted (BABA 1938, p. 31, fig. 11). The same developmental process of the gonoducts was confirmed by the regenerated tail of the mature specimens. When the tail is cut off at any point wherever, the cut end of the remaining body completely closes within 5 days. After about 10 days a small knob-like swelling appears at the same spot. Development proceeds further on. But before this swelling reaches to the formation of $2-3 \mathrm{~mm}$ long tail, it takes more than one month. The rate of development, of course, varies much according to different specimens. The regeneration of tail takes place in natural conditions as well. I have collected several specimens in which the tail portion was small and apparently in the process of regeneration.

A series of specimens in which the tail was in various stages of regeneration were fixed and sectioned for examination. Here the discussion is confined to the development of the gonoducts.

The wall of the midgut extends posteriorly into the regenerated tail and constitutes therein a narrowed rectum and a moderately spacious cloaca (fig. 23, f). Here the lining epithelium is low and bears cilia on the free edge. It is folded longitudinally. The pericardium (fig. 23, e) takes its origin from the posteriorly extended epithelium of the gonad wall. The epithelium is again low and ciliated. At a very young stage, a pair of diverticula arise from the lateral basal walls of the cloaca, a short distance anterior to the end of this organ. As development advances, they extend forward to about the level of the anterior end of the pericardium. There they make an abrupt turn backward, and pass into the postero-lateral corners of the newly formed pericardium. These 
are the rudimentary gonoducts which take the form of simply elongated canals (fig. 23, h-i). The epithelium does not differ materially from that of the cloaca, and there is no evidence that the constituting elements act as excretory cells ${ }^{1)}$. During the

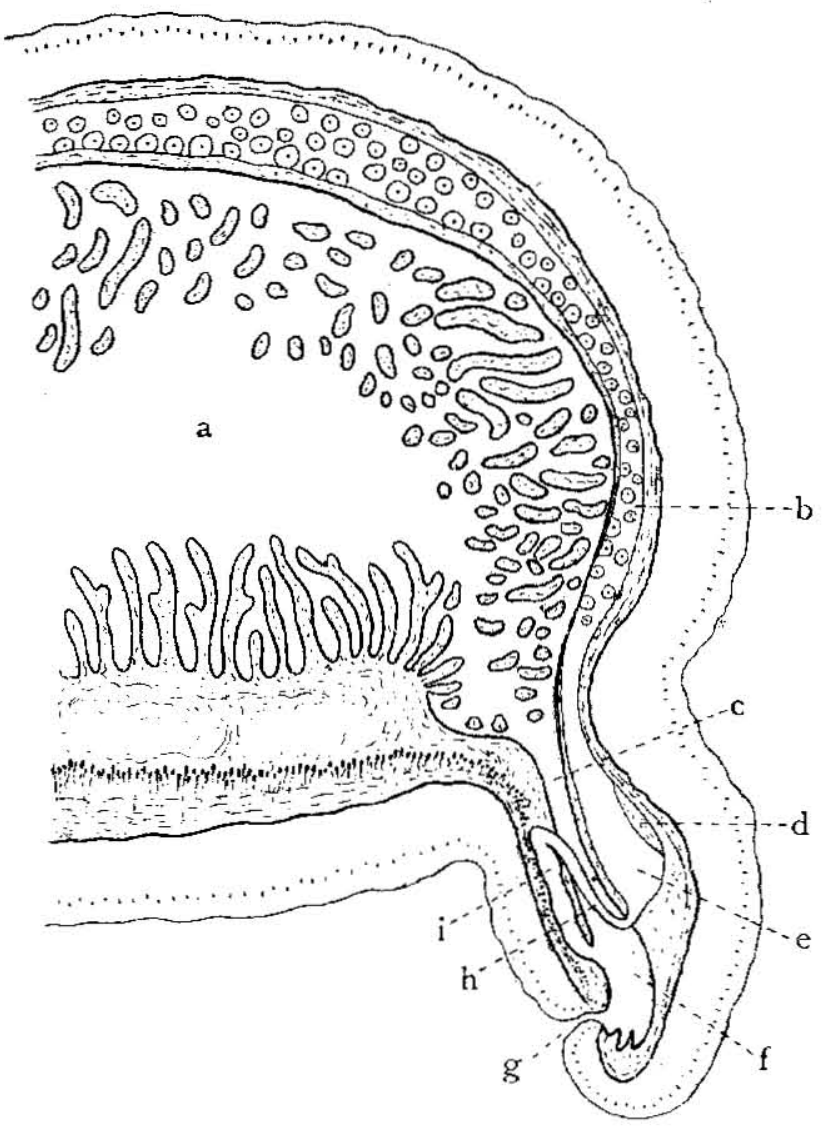

Fig. 23.-Median longitudinal section of a regenerated tail at the end of the trunk. About 50 days after operation. Half diagrammatic. a. midgut, b. gonad, c. rectum, d. heart, e. pericardium, f. cloaca, g. cloacal opening, h. upper gonoduct, i. lower gonoduct.

1) This agrees with Hsa?r's observations on Dorymenia acuta. According to him, the gonoducts in a young specimen about $14 \mathrm{~mm}$ long are simple tubes of essentially the same calibre throughout. and they show no sign of glandular activity as in mature specimens. He says "if these ducts are in part excretory this phase of activity should appear long before sexual maturity and its absence indicates that these tubes are merely for carrying off sex products" (Hfarı 1911, p. 104, see also pp. 38, 39; HofFMañ 1929, p. 94). 
further course of development, there arise a number of spermathecae, and finally the lower half of the gonoducts becomes differentiated into a mucous gland.

The cloaca in Epimenia originates from the proctodeal invagination, so the gonoducts are equally of ectodermal derivation. But in the chitons the nephridia are known to develop from the ventral lateral sides of the mesodermal coelom, each differentiating into a reno-pericardial funnel and a main body of nephridium which opens to the exterior through the renal pore (HAMmansTen and Runnström 1925, cited from HoFfmann 1929, p. 322).

\section{INJECTION METHODS}

in order to ascertain the phagocytic actions in the organisation of Epimenia, I have adopted the physiological injection of such substances as black ink") carmine particles, or olive oil droplets, into the hypodermal connective tissue or into the midgut lumen. The ingestion by phagocytosis implies also the elimination of waste or objectionable matters from the body of the animal.

\section{Hypodermic Injection ; Ingestion and Excretion by Amocbocytes}

1. Black Ink Injection

The black ink was first injected into the connective tissue just below the midgut, at about half way of the body-length, by means of an injecting syringe with a needle of $1 / 2 \mathrm{~mm}$ in thickness. The amount of ink used should vary according to the size of the animal. But for the specimens $10-15 \mathrm{~cm}$ in length an amount less than $1 / 40 \mathrm{cc}$ may suffice. When over-injected, the excess of ink remains stagnant at the spot of injection and finally causes putrefaction of tissues. Immediately after injection, the wound is closed by the contraction of the integument, so that the injected material will naturally be prevented from flowing out. A number of specimens thus injected were left in an aquarium tank for from 2 to 14 days. During this period part of

\footnotetext{
1) This is prepared by braying finely the Japanese ink-stick in sea-water. Before employment, it is better to filtrate the resulted suspension through a cotton gauze.
} 
them were dissected for fresh microscopic preparations, and the remaining specimens were fixed for celloidin sections stained with carmine.

At first the introduced black ink is seen through the integument near the spot at which the injection was made. But within two or thrce days black effect gradually disappears. When opened at this stage, it will be seen that the black ink, as it diffuses or circulates, is successively taken up by the amoebocytes and carried to various regions of the body. This clearly demonstrates the phagocytic power of the amoebocytes, but concerning the other elements of the blood, namely the erythrocytes and platelets, they show hardly any sign of ingestion. The black ink as taken in by the amoebocytes assumes the form of small and large droplets (fig. 24, A), the accumulation of which sometimes obscures the
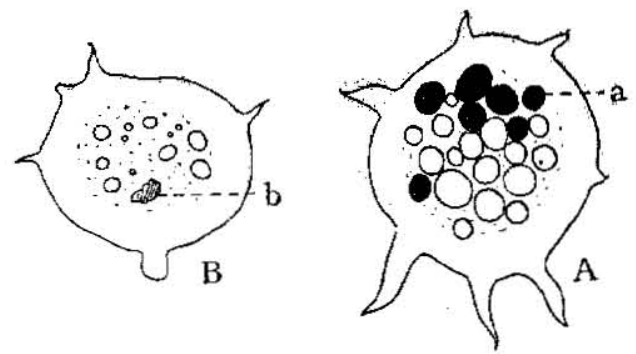

Fig. 24.-Living amoebocytes with ingested black ink droplets (a) and carmine particle (b). $(\times 1800)$.

cytoplasm from sight. - In surface view the digestive epithelia and the apices of the midgut villi appear to be stained black. But this is merely due to an accumulation of the amoebocytes with ingested black ink droplets, in the regions of the underlying connective tissue. The amoebocytes do not enter the integumental cuticular covering. The most important fact is that the gonoducts, hypodermal papillae, atrial cirri, and pedal gland-all of which were assumed by certain authors to be excretory-have practically nothing to do with the injected material.

According to observations on sections, the elimination of ingested black ink droplets commences not long after these have been taken in by the amoebocytes. The final destination of the 
droplets is in the midgut lumen, rectum and cloaca; but never in the pericardial chamber and gonoduct lumen.

i. In the Midgut, Rectum and Cloaca: The black ink droplets ingested within the amoebocytes were observed most actively discharged into the midgut lumen from among the villous cells, about two days after the black ink had been injected. The discharged droplets occasionally show a sign of being collected, because some of them are decidedly larger in size than those still contained in the amoebocytes. In this case the cells of the villi do not act as intermediaries between the amoebocytes and the midgut lumen; they are never seen receiving black ink droplets from the amoebocytes in the connective tissue. Sometimes the amoebocytes with ink droplets were found passing through the dorsal midgut epithelium. Here again the droplets are shed into the lumen of the midgut, but the amount of them after discharge

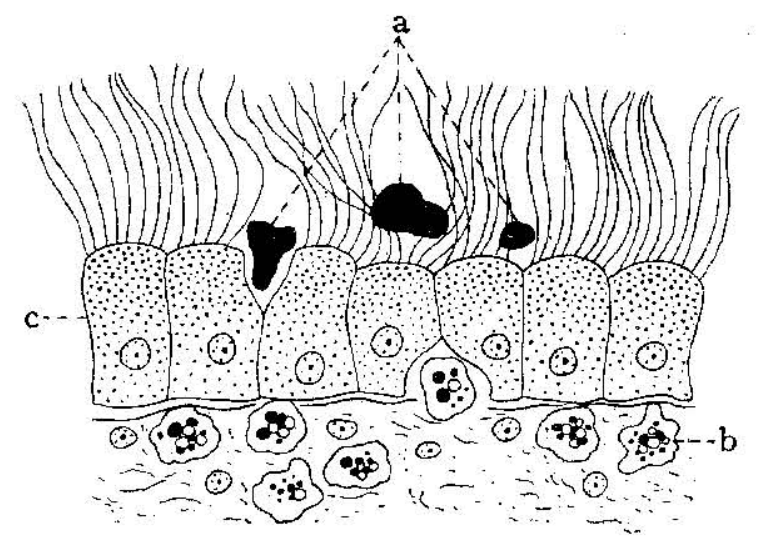

Fig. 25.-Elimination of the injected black ink by amoebocytes on the surface of the cloacal epithelium. About two days after injection. a. rejected balls of black ink, b. amoebocytes with ingested ink droplets, c. epithelial cells. $(\times 500)$.

is not so large as among the villi. The same may be said of the epithelia of the rectum and cloaca (fig. 25). The black ink droplets discharged are finally conveyed backward by the ciliary movement in these regions.

ii. Gonoducts, Pericardium: As stated before, the epithelial cells of these organs never possess a phagocytic power. But if the injected material should appear in the lumen of the pericardium 
or at least in that of the gonoducts, these two organs might still be considered as excretory. Unfortunately the facts obtained by experiments were always against this assumption. There are no amoebocytes actually found passing through the epithelial linings, nor do black ink droplets exude into the lumen of the gonoducts and pericardium. The heart contains a large number of amoebocytes with ingested black ink, but it is hardly possible to find them in the act of escaping into the pericardial chamber.

iii. In the Head Region: No specialised organs that can be identified as phagocytic were found in the head region. The pedal gland and atrial cirri are far from being excretory in function. The only phagocytic elements are here also the amoebocytes wandering in the connective tissue.

\section{Injection of Carmine Particles}

A small quantity of carmine particles suspended in sea-water were injected into the hypodermal connective tissue, and the animal was dissected within one day after injection. Carmine particles were quickly taken in by the amoebocytes (fig. 24, B). This shows that the amoebocytes have a power of ingesting solid matters as well as liquid.

\section{Injection into the Midgut Lumen; Absorption and Excretion by Villous Cells}

a. Black Ink Injection

No definite report on the mechanism of digestion in the solenogastres has up to the present been made. Recently HoFFMANN (1929, p. 118) suggested that ferment secretion and absorption might both be attributed to the structure of the so-called midgut glands, just as is the case in the Pulmonata. According to him the dorsal midgut tract and the rectum are also functional as absorptive surfaces.

The following experiments were undertaken with the hope of making clear the actual process of absorption in the digestive tract of Epimenia. For this purpose a quantity of black ink (ca. $1 / 20 \mathrm{cc})$ was injected into the midgut lumen with an injection syringe, and the animals were then freed in an aquarium tank for 
a given length of time. Examination was made either on freshly dissected specimens or on fixed and stained sections.

In case the injection is too voluminous for the animal, the excess of fluid is vomited nearly always

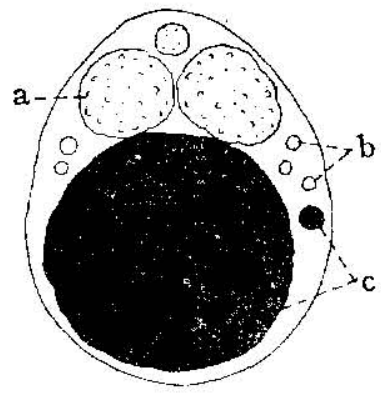

Fig. 26.-Excretoy villous cell with ingested black ink droplets (c). a. pigment granule, b. ferment granules. $(x 1300)$. by way of the atrial opening, and not from the anus!

Generally speaking, the centre of absorption in Epimenia lies entirely in the epithelia of the midgut villi, the dorsal midgut tract and the rectum taking no part in the absorption process.

i. Villous Cells: The absorptive power of the villous cells is very great. So, when animals were opened one or two days after injection, it may be seen that the whole of the midgut villi are stained dark as a result of absorption of the injected black ink. The black ink is taken in by individual villous cells (fig. 12, d), as droplets of various sizes which remain among the ferment and pigment granules, sometimes also within the vacuoles.

The ingested droplets of black ink are not long retained but many of them gradually come to be discharged directly from the villous cells, in 7 to 10 days after injection. The discharged droplets are more or less collected into conspicuous balls covered externally with a clear viscous substance (fig. 27), and these balls are found most abundantly among the villi or in the dorsal midgut lumen. Some of the ingested droplets are eliminated as they are in the vacuoles of the falling excretory villous cells (figs. 15, e; 26, c). As elimination proceeds, the villi recover their own yellowish or orange-yellow colour in about 20-30 days after they were first darkened by the injected material.

Usually there are very few amoebocytes in the lumen of the digestive tract. In the time of injection, they, of

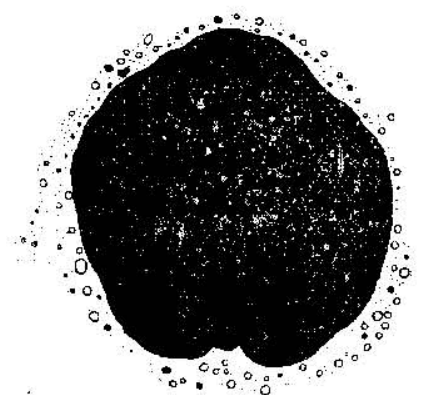

Fig. 27.-A rejected ball of black ink on the surface of the villi. $(x 120)$. 
course, attack the introduced material. But those amoebocytes which are in the connective tissue around the digestive epithelium do not appear in this case to take part in the absorption from the digestive lumen.

ii. Dorsal Midgut Tract, Pharynx, Rectum, and Cloaca: The cpithelia in these regions have practically no power of absorbing injected material.

\section{b. Injection of Carmine Particles and Olive Oil}

Injected carmine particles are quickly taken in by the villous cells (fig. 12, f), but olive oil proved rather difficult to absorb. I kept a small amount of olive oil stained red with Sudan III, in contact with the midgut villi, and examined after the lapse of half a day. A few of the villous cells were found with ingested droplets of oil, but the majority remained indifferent to such an oily substance.

\section{ABSORPTION AND EXCRETION IN NATURAL CONDITIONS}

The food of Epimenia in natural conditions is the alcyonarians, Nephthya and Dendronephthya. But the actual process as to how these are attacked, could not be observed, because the solenogastre never feeds in captivity. The foregut can be everted in the form of a proboscis ${ }^{12}$, as I have myself confirmed twice on aquarium specimens, and the radula comes to face directly towards the exterior, at about the foremost end of the proboscis. The salivary openings are situated immediately behind the radula. Under such conditions, it may be supposed that a portion of the body of alcyonarians can be cut off by means of the radula, and the cut piece then carried into the pharynx with the retraction of the proboscis. On opening the specimens taken freshly from the sea, the pharynx is often seen packed with a voluminous piece of alcyonarians. This latter consists of polyps and coenosarc, that is, the distal portion of the branch-stem.

1) For the formation of proboscis, see also Hoffmanis 1929, pp. 57-58. 
The food stuff undergoes digestion while still within the pharynx. The coenosarc and the polyps are gradually destroyed and dissolved into chyle which is then conveyed towards the midgut lumen. In this case, there is no recognisable sign that the food stuff is triturated into small pieces by the action of the radula. The colour of the chyle is orange-yellow, pink, or purplish pink, and is obviously due to different colours of the alcyonarians. The main constituent of the chyle is the digested flesh in which are included a variety of elements: (1) pigment granules, (2) oil droplets, (3) nematocysts and other formed cells, and (4) spicules.

Within the midgut the chyle is subjected directly to the phagocytic activity of the villous epithelium. Evidently the digested flesh, oil droplets and pigment granules are taken in by the cells of the villi. The colour of the villi is thus entirely affected by that of the chyle. The nematocysts and other formed cells are very rarely ingested by the villous cells, but the greater part of them remain intact within the midgut lumen. The spicules do not undergo digestion, nor absorption. They are accumulated towards the dorsal midgut tract, conveyed into the rectum and cloaca, and finally discharged as reddish or ashy excrement, according to the predominant colour of the constituent spicules.

During the time of feeding, a small amount of excrement is sometimes expelled through the cloacal opening. The colour of the excrement is pinkish white or reddish, etc., and again it is affected largely by the sort of pigment granules contained. The excrement consists of (1) the undigested debris of the alcyonarians (pigment granules, nematocysts and others), and (2) the excreted cells of the solenogastre itself (detached villous cells, erythrocytes, amoebocytes, platelets). The villous cells were mainly those with vacuoles and uric acid formations (excretory villous cells), but some of them were occupied by active cells. The blood cells were mostly intact, rarely destroyed, and their total amount was very small.

It was observed that the aquarium specimens sometimes disgorged part of the contents of the midgut lumen, accompanied by successive peristalses occurring in the anterior part of the body. Presumably these specimens were in an abnormal condition. 


\section{E. FEEDING EXPERIMENTS ; EXTRACELLULAR DIGESTION}

The villous cells have the power to digest food substances within the cell-body (intracellular digestion). But before the flesh of the prey, alcyonarians, is ingested by the villous cells, there must have taken place extracellular digestion by which the food stuff is destroyed and chylified so as to be absorbed easily. The following experiments were made with the purpose of determining the actual process of extracellular digestion in the digestive tract.

A number of animals, previously starved, were taken up. These were dissected at the middle of the body length, and tentatively fed with pieces of Nephthya and Dendronephthya, as shown in the figure 28. They were then left in an aquarium tank, and

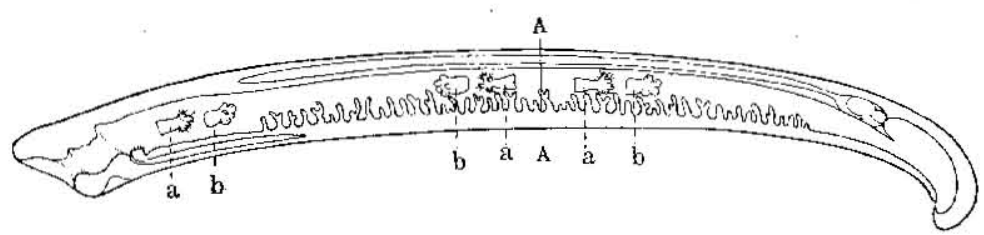

Fig. 28.-Diagrammatic representation of an animal with inserted pieces of alcyonarians. The line A-A shows the place at which the body is cut. a. Dendronephthya, b. Nephthya.

opened after the lapse of about one day. The pieces of Dendronephthya which had been kept in the pharynx and midgut lumen, were found equally well-chylified for immediate absorption. This fact shows that there had taken place an extracellular digestion of the food pieces by the ferment-containing secretions from the cells of the villi. The pieces of Nephthya, all remained in the state of half-chylification. The flesh of Dendronephthya is more quickly digestible for the solenogastre than that of Nephthya.

\section{F. SUMMARY}

1. Previously to the discussion of the problems of absorption and excretion in the organisation of Epimenia verrucosa, general anatomy and detailed topographic histology are first studied on living as well as preserved animals.

2. The hypodermal papillae are differentiated into two types: 
pigmented papillae and glandular papillae. There is no evidence that they take part in the elimination of waste matter.

3. The pedal gland is developed entirely as a mucus-supplying gland. It never has an additional excretory function.

4. The general epithelia of the digestive tract have no power of absorbing digested substance.

5. The lateral and ventral walls of the midgut give rise to a thick cluster of villi. The epithelial cells of the villi are highly glandular, and packed with clear, mostly colourless ferment granules.

6. The isolated villous cells in a moist chamber are capable of amoeboid change of form.

7. The phagocytic activity of the villous cells is demonstrated physiologically by the injection of black ink and carminc particles into the lumen of the midgut.

8. The natural food of Epimenia verrucosa consists of the alcyonarians, Nephthya and Dendronephthya. Pieces of food are digested extracellularly and chylified by the ferment-containing secretion from the villous cells. The chyle is then absorbed by the villous cells and the nutritive substances are further digested intracellularly. The pigment granules of the alcyonarians are also taken in by the villous cells.

9. When old and inactive, the villous cells become highly vacuolated and themselves are shed into the midgut lumen (excretory villous cells). In the vacuoles there are often a varying number of metabolic end-products, the concretions and crystals of uric acid. The villous cells have also the power to eliminate directly the objectionable matter they have ingested.

10. The blood-plasma is clear and colourless, and is noncoagulable. There are three main kinds of blood-corpuscles : erythrocytes, amoebocytes, and platelets. The amoebocytes are packed with a varying number of clear, mostly colourless ferment granules.

11. Black ink and carmine particles injected hypodermically into the connective tissue are quickly ingested by the amoebocytes. The foreign material is then discharged by way of the epithelium of the midgut villi, dorsal midgut tract, rectum, and cloaca, but never rejected into the pericardium and gonoducts. The amoebocytes thus play an important part in excretion.

12. The gonoducts are of ectodermal origin, and structurally 
specialised for carrying off sexual products. They never function in true excretion.

13. The gonoducts cannot be homologised with the chiton nephridia. These two differ from each other fundamentally in their origin, structure, and function. In other words, the chiton nephridia are derived from the mesodermal coelom, and have the structure and function of an excretory organ.

(Amakusa Marine Biological Laboratory, Tcmioka, Kumamoto-k(n, Japan)

\section{LITERATURE}

BAeA, K. 1938 The later development of a solenogastre, Epimenia verrtucosa (Nifr5TR.4s7). Jour. Dept. Agric. Kyüsyü Imp. Univ., vol. 6, no. 1.

1939 Preliminary note on Epimenia verrucosa (Niérstrasz), a solenogastre species from Amakusa, Japan. Venus, vol. 9, no. 1

HFarit, H. 1911 The solenogastres. Mem. Mus. Comp. Zool. Harvard Coll., vol. 45, no. 1.

1918 Solenogastres from the eastern coast of North America. Ditto. vol. 45, no. 2 .

Hirasaka, K. 1930 Mollusca. Feeding habits. Iwanami Koza, Biology (in Japanese). Hoffmasi, H. 1929 Aplacophora: Klassen und Ordnungen des Tier-Reichs. Bd. 3, Abt. 1. Nachtr. 1-Polyplacophora. Ditto, Bd. 3, Abt. 1, Nachtr. 2.

Nifrstras\%, H. F. 1908 Mollusca, Solenogastres. Nation. Antarctic Exped, Nat. Hist., vol. 4.

Onhner, N. 1921 Norwegian solenogastres. Bergens Mus. Aarb. 1918-19, no. 3.

TAKatsuki, S. 1934 On the nature and functions of the amoebocytes of Ostrea edulis. Quart. Jour. Micr. Sci., vol. 76, pt. 3.

Thlliz, J. 1894 Beiträge zur vergleichenden Anatomie der Amphineuren. I. Über einige Neapeler Solcnogastres. Zeitschr. f. wiss. Zool., Bd. 58. 


\section{EXPLANATION OF THE PLATES}

\section{Plate 14}

Median longitudinal section of head region. Half diagrammatic. a. atrial cirri, b. cerebral ganglion, c. foregut, d. pharynx, e. radula, f. gonad, g. right salivary gland, h. midgut, i. pedal gland, j. left salivary gland, k. salivary duct, 1. prepedal cavity, m. circumbuccal ridge, n. atrium.

\section{Plate 15}

Longitudinal section of tail region, slightly to the left of the middle line. Fialf diagrammatic. a. gonad, b. gono-pericardial canal, c. ventricle, d. auricle, e. dorsal cloacal chamber, f. opening of lower gonoduct (j) into cloaca (i), g. dorso-terminal sense organ, h. cloacal opening, k. rectum, 1 . pericardium, m. midgut. 
Jour. Dept. Agric. Kyūsyū Imp. Univ. Vol. 6

Plate 14

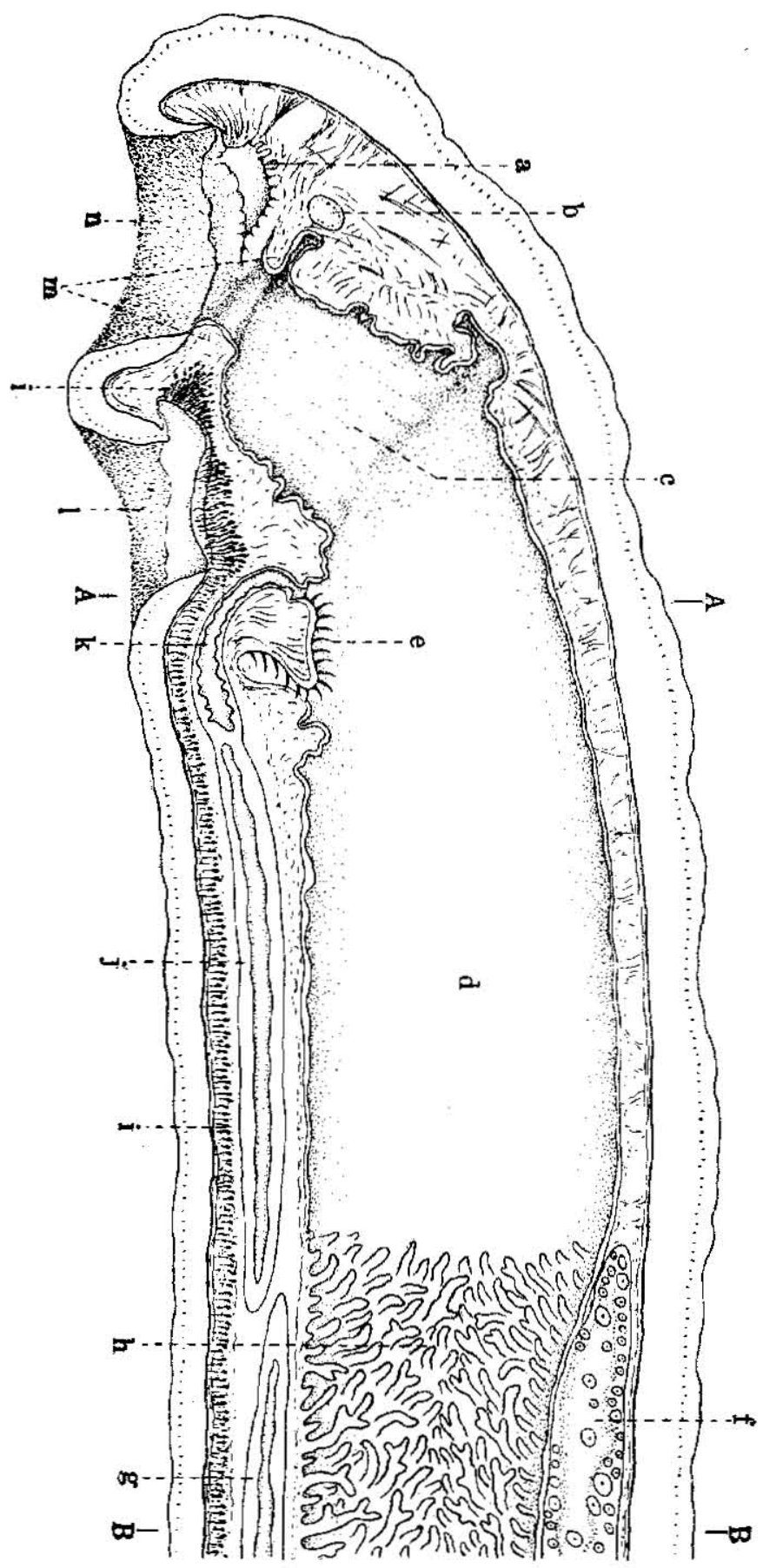




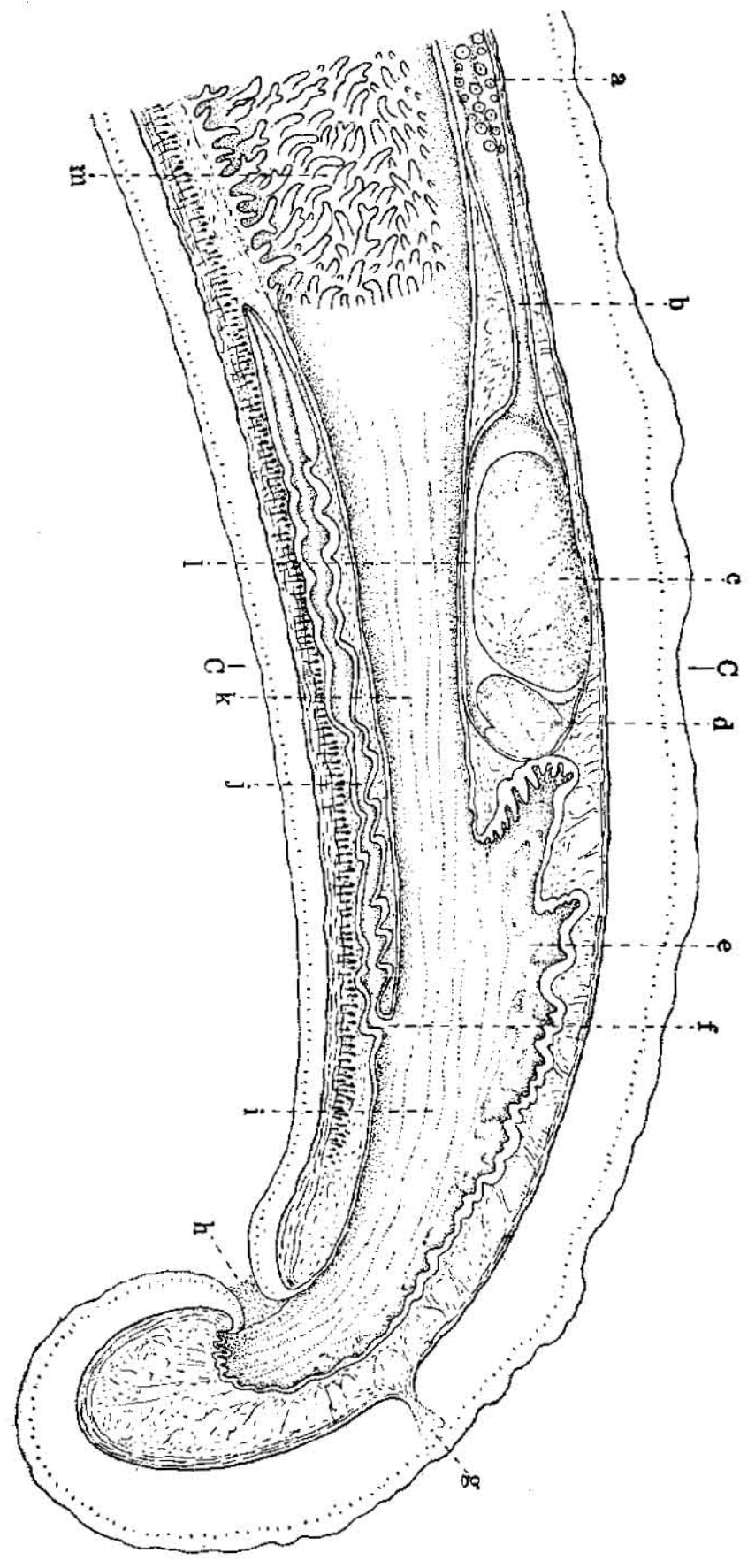

